\title{
Szinonímia a feledésbe + ige típusú funkcióigés szerkezetek körében*
}

A jelen dolgozat a funkcióigés szerkezetek körében megmutatkozó szinonímia jelenségével foglalkozik elsősorban problémafelvető jelleggel és csupán egyetlen szinonimakört, a feledésbe + ige 'elfelejtődik' konstrukció különböző variánsait (pl. feledésbe merül kerül megy enyészik) elemezve. A funkcióigés szerkezetek fogalmának és típusainak felvázolása (1.), a kutatás fó célkitüzéseinek ismertetése (2.) és a feldolgozott anyag bemutatása (3.) után áttekintem, hogy tipikusan milyen metaforikus kifejezéseket alkalmazva ragadhatjuk meg az emlékezés és a felejtés egymástól elválaszthatatlan fogalmát, illetve hogy ezen lehetséges kifejezési módok sorába hogyan illeszkednek a vizsgált feledésbe $V$ szerkezetek (4.). Ezt követően, a dolgozat 5. alpontjában arra keresem a választ, hogy a konstrukció különböző variánsaiban előforduló egyes igék hogyan léphetnek be az adott szerkezetekbe, és milyen specifikus mozzanatokkal járulnak hozzá a szerkezet jelentéséhez - vagyis milyen specifikus nézőpontból teszik hozzáférhetővé nyelvileg a felejtés folyamatát. Mindezek után, a 6. alpontban azzal a kérdéssel foglalkozom - elsősorban szinkrón szempontból, de amennyire ezt a rendelkezésre álló nyelvi adatok lehetővé teszik, a feltételezhető diakrón változásokat is tekintetbe véve -, hogy az adott szinonimakörön belül mely szerkezet(ek) és miért tekinthetö(k) központinak. A dolgozatot rövid összegzés és a további lehetséges kutatási irányokat felvázoló kitekintés zárja (7.).

\section{A funkcióigés szerkezetek fogalma és típusai}

A funkcióigés szerkezeteket a szakirodalom jelentős része olyan kéttagú, egyetlen igével helyettesíthető igei szerkezetekként értelmezi, amelyek jelentését a szerkezet névszói eleme határozza meg (pl. javaslatot tesz). E szerint a felfogás szerint az ilyen típusú szerkezetekben megjelenő (funkció)igék deszemantizálódott, szemantikailag „üres”, nem teljes értékü igék, amelyek szerepe jellemzően csupán az, hogy a hozzájuk kapcsolódó névszót képessé tegyék az állítmányi pozíció betöltésére (vö. pl. Langer 2005; Keszler 2000; Hegedűs 2004: 246; Forgács 2007: 48, 85-7). Ugyanakkor a magyar nyelvü szakirodalom példaanyagát megvizsgálva jól látható, hogy a funkcióigésnek tartott kifejezések jelentősen eltérnek egymástól a tekintetben, hogy igei elemeik jelentése milyen mértékben általános (és adott esetben egyben grammatikalizálódott) jelentés. Egyes funkcióigék valóban főként grammatikai jellegü, tipikus esetben képzők által kifejezett mozzanatokkal - például az okozás vagy a folyamatosság mozzanatával (vö. pl. szelid-it 'okozza, hogy szelíd legyen') - járulnak hozzá a szerkezet jelentéséhez (pl. szelíddé tesz 'okozza, hogy szelíd legyen');

\footnotetext{
* Hálásan köszönöm Ladányi Máriának a kutatás és a tanulmány elkészítése során nyújtott segítségét. Köszönettel tartozom továbbá az ELTE DiAGram Funkcionális Nyelvészeti Műhely tagjainak a kézirathoz füzött észrevételeikért. A tanulmány az Innovációs és Technológiai Minisztérium ÚNKP-20-3 kódszámú Új Nemzeti Kiválóság Programjának, valamint az NKFIH 129040 számú pályázatának (A magyar nyelv igei konstrukciói. Használatalapú konstrukciós nyelvtani kutatás) támogatásával készült.
} 
a szakirodalmi példák között azonban számos olyan kifejezést is találunk, amelyekben az igei elem funkciója nyilvánvalóan nem pusztán grammatikai funkció (pl. foglyul ejt, rendszerbe foglal - Forgács 2007: 85-7; barátságot köt - Hegedüs 2004: 248; ${ }^{1}$ a funkcióigék szemantikai sajátosságaival összefüggésben lásd még: Cetnarowska 2014; Lanstyák 2019).

Dolgozatomban mindezeket - valamint saját korábbi kutatásaimat (Hrenek 2016) - figyelembe véve a funkcióigés szerkezeteket a metaforikus jelentésü igei szerkezetek egy sajátos, heterogén csoportjaként értelmezem; olyan igei kifejezésekként igyekszem megragadni őket, amelyek felcserélhetők ${ }^{2}$ egyetlen igével, ${ }^{3}$ és amelyek névszói eleme morfológiai szempontból is egyértelmüen kötődik a szerkezettel szinonim igéhez (ahogyan például a tanácsot ad szerkezet tanácsot eleme morfológiailag is kötődik a szerkezettel szinonim tanácsol igéhez). ${ }^{4}$ Ez az értelmezés tehát - a szakirodalomban elterjedt és a korábbiakban hivatkozott megközelítésekkel szemben - nem az ige jelentésének általánossága alapján határozza meg az adott szerkezettípust: az a szempont, hogy a szerkezetben megjelenő (funkció) ige jelentése milyen mértékben tekinthető általános, illetve grammatikai jelentésnek, ebben a megközelítésben nem a definíció alapjaként, hanem egy lehetséges belső rendszerezési elvként jelenik meg. A funkcióigés szerkezetek a bennük szereplö igék funkcióját, sematizáltságának, grammatikalizáltságának mértékét - amely értelmezésem szerint nem kvantifikálható, de korpuszalapú kvalitatív jelentéselemzésekkel jól megragadható -, illetve a metaforizációs folyamatok sajátosságait ${ }^{5}$ figyelembe véve alapvetően négy fő csoportba rendezhetők (részletesebben lásd Hrenek i. m.).

1 Az ilyen szerkezetek funkcióigés szerkezetekként való megjelölését elsősorban az indokolja, hogy ezek mindegyike helyettesíthetö egyetlen, a szerkezet névszói elemével morfológiailag rokon igével (pl. foglyul ejt elfog, rendszerbe foglal $\sim$ rendszerez, összeesküvést szö $\sim$ összeesküszik).

2 A helyettesíthetőség vagy felcserélhetőség fogalma számos további, a szinonímia jelenségének értelmezéséhez (is) szorosan kapcsolódó kérdést felvet, amelyek egy részét a következőkben ismertetett elemzések eredményeinek bemutatása során érintőlegesen említeni fogom. A jelen dolgozatnak azonban nem célja, hogy ezt a(z adott téma szempontjából természetesen alapvető fontosságú) kérdéskört elméleti szempontból és szisztematikusan is megvizsgálja.

3 A szinonim ige megléte vagy hiánya összefügg azzal, hogy az adott nyelvben mi lexikalizálódik, illetve lexikalizálódhat (vö. pl. fehérré válik fehérit, de bolhacirkusszá válik ?(el)bolhacirkuszosit; megfelelő kontextusban az (el)bolhacirkuszosit szó is létrehozható, ez azonban egyedi és alkalmi, nem konvencionális kifejezés). Erre a kérdésre azonban itt nem térek ki részletesebben.

4 A funkcióigés szerkezetekkel foglalkozó szakirodalom gyakran etimológiai rokonságot említ (vö. pl. Dobos 2005; Náray-Szabó 2010). A két megnevezés adott esetben ugyanarra a kapcsolatra vonatkozik - mivel azonban a jelen dolgozat nem történeti szemléletü, itt pontosabb etimológiai helyett morfológiai összefüggésekröl beszélni.

5 A típusok körvonalazásakor figyelembe vett szempontok - az igei jelentés sematikussága, grammatikalizáltsága és illeszkedése az ige teljes jelentésrendszerébe - szorosan összefonódnak egymással, így ezeket adott esetben együttesen tárgyalom. A nagyobb mértékü sematikusság, illetve grammatikalizáltság ugyanakkor nem jelent egyúttal nagyobb mértékủ metaforikusságot is. Ebben az értelmezési keretben a metaforikusság nem tekinthető fokozati kérdésnek. 
Az egyes csoportok (különösen a 2. és a 3. kategóriába sorolható kifejezések) azonban nem különülnek, illetve nem különíthetők el élesen egymástól, így egyértelmű körülhatárolásukra nem is vállalkozom; rendszerezésük során csupán a közöttük lévő (fokozati jellegü) különbségeket veszem tekintetbe:

1) Az első típusba azok a szerkezetek tartoznak, amelyekben az igék jelentése nem vagy csak egészen kis mértékben grammatikalizálódott metaforikus jelentés ${ }^{6}$ specifikus mozzanatokkal (pl. kérdésekkel bombáz 'gyors egymásutánban, sokat, fenyegetően kérdez'). Ide sorolható többek közt az átkokat zúdít [vkire], a zajt csap és a szikrákat szór kifejezés is.

2) A második típus olyan funkcióigés szerkezeteket foglal magába, amelyekben az igék jelentése - az előző csoporthoz viszonyítva - kevésbé specifikus (pl. szövetséget $\boldsymbol{k o ̈ t}$ ). Ezeknek az igéknek a lexikai jelentése rendszerint a szerkezettel szinonim, az adott/ábrázolt szituációra közvetlenül vonatkozó igék (adott esetben: szövetkezik) jelentésének egy (a bombáz típusú igékhez képest) valamivel általánosabb mozzanatát ('összekapcsolódás') emelik ki. Itt említhető például a reményt táplál, az összeesküvést szö és a virágba borul szerkezet is.

3) A harmadik típusba sorolható szerkezetek (pl. a tanácsot ad) esetében a funkcióige jelentése szintén a szinonim ige (a tanácsol) jelentésének egy általános mozzanatára épül - ez a mozzanat ('rendelkezésre bocsát') azonban ebben az esetben még általánosabb, mint az előző kategória esetében. Az ilyen típusú szerkezetekben megjelenő (funkció)igék jelentése lexikai, de sematikusabb jelentés. Néhány további példa: döntést hoz, köszönetet mond, bérbe vesz.

4) A negyedik típust azok a funkcióigés szerkezetek alkotják, amelyekben az ige jelentése különösen általános (sematikus), és ezzel együtt jelentős mértékben grammatikai jellegü (pl. vitát folytat). Az ilyen típusú kifejezések bizonyos értelemben átmenetet képeznek a funkcióigés szerkezetek mint grammatikai jelentésủ (folytat 'folyamatosan [tesz vmit]') igét tartalmazó analitikus igék ${ }^{7}$ és a grammatikai elemet (képzőt) tartalmazó szintetikus igék között. Például: elöadást tart, javaslatot tesz, sérülés(eke)t okoz.

A különböző típusú szerkezetekben szereplő (funkció)igék jelentése különböző mértékben tekinthetö általánosnak/sematikusnak (vö. bombáz - köt $-a d-f o l y t a t$ ), és a szerkezetek mint egységek jelentései is az általánosság/sematikusság különböző szintjein állnak. Az egyes szerkezettípusok így nem egyformán tág valóság-összefüggések ábrázolására képesek (vö. Zsilka 1978). A kérdésekkel bombáz típusú szerkezetek igei eleme nem pusztán a lezajló folyamatot nevezi meg, hanem az adott

6 A jelen kutatás során - a szerves nyelvelmélet terminológiáját követve (vö. pl. Zsilka 1978) - minden olyan jelentést metaforikusnak tekintek, amely nem tulajdonképpeni jelentés. Ez a megközelítés a kutatásaimban a későbbiekben további árnyalást igényel; a jelen kutatás eredményeinek értelmezésére azonban a tulajdonképpeni és a metaforikus jelentések meghatározása érdemben nincs hatással.

7 A funkcióigés szerkezetek mint analitikus igék mondattani szempontból komplex protoállításokként (Imrényi 2013) is megragadhatók. 
folyamat bizonyos, a megnyilatkozó által az adott beszédhelyzetben lényegesnek tartott körülményeire is utal (pl. a kérdésekkel bombáz igei eleme azt emeli ki, hogy az ábrázolt jelenetben - a megnyilatkozó interpretációja szerint - gyors egymásutánban sok kérdés követi egymást, és ez fenyegető lehet). A szövetséget köt, a tanácsot ad és a vitát folytat típusba sorolható szerkezetek esetében ezzel szemben a funkcióige az ábrázolt esemény egy inherens (vagy akként értelmezett) jellemzőjére irányítja a figyelmet - tehát a folyamatra magára vonatkozik anélkül, hogy annak módjára vagy körülményeire is vonatkozna. Ugyanakkor ezen három típus is eltér egymástól a tekintetben, hogy a szerkezetek mennyire specifikusan, illetve mennyire részletesen ábrázolják az adott jelenetet. A szövetséget köt mintegy értelmezi (az említett 'összekapcsolódás' mozzanattal összefüggésben kölcsönös elköteleződéssel járó, alapvetően szimmetrikus kapcsolat létrehozásaként jeleníti meg) azt az eseményt, amelyre utal. A tanácsot ad a folyamat egy jellemző - az adott megnyilatkozó által fontosnak tartott - összetevőjét emeli ki ('rendelkezésére bocsát'); a vitát folytat igei eleme pedig mindössze az adott tevékenység folyamatosságát, időbeli kiterjedtségét jelöli - az ilyen szerkezetek jellemzően tehát a körülményekről nem árulnak el semmit. (A funkcióigék és vonzataik közötti kapcsolatról lásd pl. Dobos 2005, Hrenek 2019a.)

Az egyes típusok éles elhatárolhatóságáról azonban - ahogyan erre korábban is utaltam - természetesen egyetlen esetben sem beszélhetünk. ${ }^{8}$ A funkcióigés szerkezetek itt felvázolt, egymással szorosan összefüggő típusai egy olyan skálán helyezhetők el, amely egyfelől a nagyon specifikus jelentésü igei szerkezetek felé, másfelől pedig a nagymértékben sematikus (grammatikai) jelentésű igét tartalmazó szerkezetek, illetve a grammatikai elemet (képzőt) tartalmazó, komplex morfológiai felépítésü igék felé nyitott. ${ }^{9}$ Ezt a skálát szemlélteti az 1 . ábra:

\begin{tabular}{|c|c|c|c|c|c|c|}
\hline $\begin{array}{c}\text { narancsokkal } \\
\text { bombáz }\end{array}$ & $\begin{array}{c}\text { kérdésekkel } \\
\text { bombáz }\end{array}$ & $\begin{array}{c}\text { szövetséget } \\
\text { köt }\end{array}$ & $\begin{array}{c}\text { tanácsot } \\
\mathbf{a d}\end{array}$ & $\begin{array}{c}\text { vitát } \\
\text { folytat }\end{array}$ & $\begin{array}{c}\text { nehézzé } \\
\text { tesz }\end{array}$ & \\
\hline
\end{tabular}

1. ábra. A funkcióigés szerkezetek a metaforikus jelentésü igei szerkezetek rendszerében

A feledésbe $V$ 'elfelejtődik' szinonimakörhöz tartozó kifejezések - ahogyan ezt a dolgozat 5. és 6 . alpontjában tárgyalt összefüggések is alátámasztják - többek közt

\footnotetext{
${ }^{8}$ A rendszerezésnek nem célja, hogy az egyes konkrét szerkezetek típusokba sorolásához nyújtson egyértelmủ szempontokat; csupán a vizsgált kategória belső változatosságára és a funkcióigeként használt nyelvi elemek szemantikai sokszínüségére kívánja felhívni a figyelmet. (A funkcióigés szerkezetek kategóriájának belső változatossága természetesen nem csupán az igei elemek szemantikai sajátosságaival függ össze: éppilyen fontos lehet például a névszó jelentése vagy a szerkezet és a vele szinonim ige közötti szemantikai kapcsolat jellege is. A jelen dolgozat keretein belül azonban az adott kategória részletes, átfogó jellemzésére, illetve a prototipikus és kevésbé prototipikus funkcióigés szerkezetek különböző jellegzetes vonásainak tárgyalására nincs mód.)

9 Az itt bemutatott skála a tárgyalt igei kifejezések közötti szinkrón összefüggéseket igyekszik megragadni. A funkcióigék lehetséges grammatikalizációs folyamatainak kérdésével, illetve a funkcióigés szerkezetek diakrón szemléletü leírásával (vö. pl. Ittzés 2015, 2016; Bowner 2008; Butt-Lahiri 2013) a dolgozat keretein belül nem foglalkozom.
} 
a tekintetben is eltérnek egymástól, hogy a bennük szereplö funkcióige jelentése milyen mértékben specifikus vagy általános. Ennek megfelelően a szinonimakör különböző tagjai a funkcióigés szerkezetek más-más típusaihoz tartoznak (pl. a $f e-$ ledésbe szitál a kérdésekkel bombáz, míg a feledésbe merül a szövetséget köt típusba sorolható; vö. 6.3.).

Ha egy funkcióigés szerkezet és egy vele szinonim ige szemantikai közelségét vagy távolságát vizsgáljuk, akkor plauzibilisnek tünik a feltételezés, hogy minél specifikusabb a funkcióige jelentése - vagyis minél több specifikus mozzanattal járul hozzá ez az elem a szerkezet jelentéséhez -, annál nagyobb az adott szerkezet és a vele szinonim ige közötti szemantikai távolság. ${ }^{10}$ Például az általános jelentésü igét tartalmazó kérdéseket intéz [vkihez] kifejezés - amelyben az ige nem specifikálja a kérdezés módját, körülményeit, és a megnyilatkozó attitüdjeire sem utal közvetlenül - feltehetően szemantikailag és használati körét tekintve is közelebb áll a szinonim kérdez igéhez, mint a specifikus igei elemével a kérdezési folyamatok egy sajátos módjára vonatkozó kérdésekkel bombáz [vki(ke)t] szerkezet.

A jelen kutatásom azonban a feledésbe $V$ 'elfelejtődik' szinonimakört vizsgálva rámutat arra, hogy ez az összefüggés - bár valóban fennállhat - elsősorban a funkcióigés szerkezetek egyes típusainak fent említett elkülönítésében játszik szerepet. A következőkben azonban nem az egyes kifejezések besorolására, hanem a közöttük lévő viszonyok feltárására, illetve a szinonimakör szerveződésével összefüggő kérdésekre fókuszálok.

\section{A kutatás fố célkitűzései: kutatási kérdések}

A funkcióigés szerkezetek körében megmutatkozó szinonímia jelenségének, sajátosságainak jobb megismerésére irányuló esettanulmányomban egyetlen szinonimakörrel ${ }^{11}$ foglalkozom részletesen: a feledésbe + ige (feledésbe $V$ ) sémát követő

${ }^{10}$ A szemantikai közelséget kvalitatív, a szerves nyelvelmélet elemzési metódusaira támaszkodó (vö. pl. NyMDK. 1-11) megközelítésben, a nyelvi egységek jelentésrendszerei közötti részleges átfedésként, illetve hasonlóságként értelmezem - alapvetésnek tekintve, hogy a jelentésmozzanatok megléte/hiánya és a szemantikai távolság mértéke a nyelvi jelentések természetéből adódóan nem objektív, és nem kvantifikálható. (Természetesen elfogadva emellett azt is, hogy kvantitatív módszerekkel jól megragadható jellegzetességek, mintázatok is utalhatnak az egyes kifejezések bizonyos szemantikai, illetve használatbeli sajátosságaira (pl. Divjak 2006; Glynn 2014; Glynn 2016; Glynn-Robinson [eds.] 2014; Janda-Solovyev 2009; Simon 2016, 2018). A döntően a nyelvi egységek kollokációira, használati kontextusaira és/vagy a jelentések általános mozzanataira fókuszáló vizsgálatok azonban elméleti és módszertani szempontból sem hangolhatók össze a jelen dolgozatban megfogalmazott kutatási kérdéseimmel.)

${ }^{11}$ A szinonimakörök dinamikusan változó és az öket alkotó tagokkal folyamatos kölcsönhatásban lévő elrendeződések. Az egymással (különböző jelentésváltozási folyamatok eredményeként, lásd pl. Ladányi 1993, 2004; Horváth 1996) egyes jelentéseikben szinonim viszonyba kerülő nyelvi egységek nem egyszerüen belépnek egy adott szinonimakörbe, hanem maguk is hatnak azokra a szinonimakörökre, amelyeknek a tagjaivá válnak: módosíthatják, újraértelmezhetik azokat a jelentésmozzanatokat vagy jelentésmozzanat-együttállásokat, amelyek a szóban forgó szinonimakört összetartják, illetve meghatározzák. Erre 
igei szerkezetek (pl. feledésbe merül kerül megy vész $\sim$ enyészik $\sim$ süllyed) korpuszbeli előfordulásait elemzem. ${ }^{12}$ A Magyar nemzeti szövegtár (a továbbiakban: MNSZ2) adataira épülő kutatás három - több részkérdést átfogó, illetve magába foglaló - kérdéskört vizsgál:

1. Hogyan jelenik/jelenhet meg a nyelvben az emlékezés és a felejtés (egymástól elválaszthatatlan) folyamata, illetve fogalma - vagyis milyen (nyelvi) összefüggés-rendszerben értelmezhető a kutatás szük értelemben vett tárgyát képező feledésbe $V$ konstrukció?

2. Hogyan jön létre a feledésbe $V$ 'elfelejtödik' konstrukció, illetve hogyan léphetnek be, miként illeszkednek ${ }^{13}$ ebbe a konstrukcióba a különbözö jelentésü igék (pl. tünik, múlik, enyészik)? A konstrukció egyes megvalósulásai hogyan viszonyulnak egymáshoz szemantikai szempontból, és milyen specifikus nézőpontból, mely sajátosságait előtérbe helyezve jelenítik meg az egyes kifejezések a felejtés folyamatát?

3. Milyen viszonyban áll a feledésbe $V$ kifejezések jelentése a szinonim elfelejtődik ige jelentésével? Hogyan szerveződik a feledésbe $V$ 'elfelejtődik' szinonimakör? Összefügg-e, és ha igen, hogyan függ össze a szinonimakör szerveződése az egyes funkcióigei jelentések sematikusságának mértékével? Mely szerkezet(ek) áll(nak) a szinonimakör középpontjában, és - a rendelkezésre álló adatok tanúsága szerint - ennek milyen okai lehetnek?

A kérdésekre kvalitatív módszerekkel, elsősorban az MNSZ2 korpuszát, az igei szerkezetek vizsgálatára kidolgozott Mazsola keresőeszközt és a Magyar Történeti Szövegtár (a továbbiakban: MTSZ) adatait felhasználva keresem a választ. A jelentéselemzések során a szerves nyelvelmélet (vö. pl. Zsilka 1978; Kelemen-LadányiSpannraft 1985; NyMDK. 1-11) elemzési metódusait veszem alapul.

Mivel azonban az egyes kérdéskörök vizsgálata során - az említett kereteken belül - más-más módszertani eljárásokat alkalmaztam, a különböző részkutatások módszertani hátterét az adott kérdéskört részletesen bemutató alponton belül és az

a kérdéskörre azonban a jelen dolgozat keretein belül nincs mód részletesen kitérni. A vizsgált feledésbe V'elfelejtődik' szinonimakört a korpuszadatok (vö. 3. alpont) ismeretében körvonalaztam.

${ }^{12}$ A szinonímia jelenségével - értelmezési lehetőségeivel, (feltételezhető) fokozataival, más jelentésviszonyokkal való összefüggéseivel stb. - részletesen és elméleti szempontból a dolgozat keretein belül nem foglalkozom. A szinonímiát a különböző nyelvi kifejezések jelentései közötti hasonlóságként értelmezem, amely közös(ként értelmezett) jelentésmozzanatokra épül (vö. pl. Ladányi 1993), és szorosan összefügg, de nem azonosítható problémátlanul a felcserélhetöség fogalmával (vö. pl. Murphy 2003). A prototipikus szinonim viszony sajátosságainak, illetve a szinonímia szemantikai és stilisztikai alapjainak körvonalazása túlmutat a jelen kutatás célkitüzésein, és további vizsgálatok tárgyát képezi.

${ }^{13}$ A konstrukció természetesen nem független azoktól a konkrét kifejezésektől, amelyekre a dolgozatban variánsokként hivatkozom, az igék pedig nem egy statikus, eleve adott keretként értelmezett szerkezetbe lépnek be: a különböző igei elemek maguk is visszahatnak a konstrukcióra, illetve (részben) újraértelmezhetik az adott konstrukciót (vö. 3.1.). 
adott (rész)téma kapcsán feldolgozott anyag sajátosságainak ismertetésével összekapcsolva tárgyalom.

A kutatás során a szerves nyelvelmélet szemléleti keretét és terminológiáját (vö. pl. Zsilka 1975, 1978) tekintem kiindulópontnak, illetve támaszkodom a funkcionális kognitív nyelvészet (vö. pl. Imrényi-Kugler-Ladányi-Markó-Tátrai-Tolcsvai Nagy 2017) releváns alapvetéseire és eredményeire, valamint felhasználom a funkcióigés szerkezeteket más megközelítésekben vizsgáló munkák (pl. Dobos 2009; Lanstyák 2019) egyes megállapításait is. A jelen dolgozat azonban - esettanulmány jellegéből adódóan, illetve a felvázolt kutatási kérdésekkel összhangban - a felmerülő témakörök elméleti vonatkozásaival szisztematikusan és részletesen nem foglalkozik.

\section{A vizsgált konstrukció és a vizsgálatba bevont anyag sajátosságai}

\subsection{A feledésbe $V$ 'elfelejtődik' konstrukció}

A feledésbe $V$ 'elfelejtődik' konstrukció feltehetően a feledésbe + mozgásige (különösen a feledésbe megy/merül [vö. 6.2.]) szerkezetekre épül, és (sematikus) konstrukciós jelentése is ezekben a szerkezetekben jött létre, illetve ezekből absztrahálódott. A konstrukciós séma kialakulása után azonban, a konvencionálissá vált feledésbe megy/merül kifejezések mozgásigéinek analógiájára, más mozgásigék és a konstrukció mint egység sematikus jelentéséhez kapcsolódó további igék - például a felejtés egy inherens mozzanatát elötérbe állító múlik - is beléphettek a szerkezetbe (vö. 5.2.). Ezek a szerkezetben megjelenő új igék, illetőleg a létrejövő új szerkezetek, variánsok maguk is visszahatnak a szóban forgó konstrukció jelentésére - az igék tehát nem egyszerüen beilleszkednek egy már meglévő, eleve adott keretbe, hanem alakít(hat)ják, árnyal(hat)ják, módosít(hat)ják is azt a konstrukciót, amelyben elöfordulnak (vö. 13. lábjegyzet). ${ }^{14}$

A különböző variánsok - vagyis a más-más igéket tartalmazó, de azonos névszói elemmel alkotott, szemantikai és szerkezeti szempontból is azonos sémára épülö funkcióigés kifejezések (pl. feledésbe merül enyészik oszlik) - jelentését ugyanaz a közös általános mozzanat, az 'elfelejtődik' mozzanat határozza meg, így az említett szerkezetek egy (dinamikusan értelmezett, vö. 11. lábjegyzet) szinonimakör tagjaiként ragadhatók meg.

\subsection{A vizsgálatba bevont kifejezések köre}

A feledésbe $V$ 'elfelejtődik' szinonimakörhöz tartozó különböző funkcióigés szerkezetek listáját az MNSZ2 segítségével állítottam össze. A feledésbe szóalak va-

${ }^{14}$ Langacker (2009) ezt a skewing (igazodás) fogalmának bevonásával tartja megragadhatónak. (A skewing jelenségét vizsgálja magyar anyagon, a magyar rezultatív konstrukciókat elemezve Kugler Nóra [2021] is.) Ennek a megközelítésnek a jelen dolgozat értelmezési keretével való összeegyeztetése azonban további kutatásokat igényel, így az itt bemutatott vizsgálataim során nem alkalmazom a skewing fogalmát. 
lamennyi korpuszbeli előfordulását magába foglaló, összesen 3115 elemü teljes találati listáról manuálisan kiszürtem azokat a kifejezéseket, amelyekben a szerkezet 'elfelejtődik' jelentésben szerepel, listába szedtem az ezen szerkezetekben megjelenő igéket, majd (ugyancsak az MNSZ2-ben) célzott kereséssel külön-külön rákerestem az adott feledésbe $+V$ szerkezetekre.

A keresések során a feledésbe - természetesen - szóalakként, míg a vele együtt álló igei elem szótőként szerepelt; ebböl, illetve a korpusz sajátosságaiból adódóan a találati listák az igei kifejezések mellett az igenévi elemet tartalmazó szerkezeteket is tartalmazták. Ezeket a találatokat nem távolítottam el manuálisan sem a feldolgozott anyagból, mivel feltételeztem, hogy ha egy ilyen típusú kifejezésben egy adott elem elöfordulhat igenévként, akkor - még ha ez korpuszadatokkal nem is támasztható alá minden esetben - elvileg igeként is megjelenhet, vagyis az igével alkotott forma is elfogadható, potenciálisan létező (és a vizsgált szinonimakörbe jól illeszkedő) kifejezés.

A feledésbe $V$ 'elfelejtődik' szinonimakörhöz az MNSZ2 adatai szerint az alábbi, 1. táblázatban (betürend szerint) felsorolt kifejezések tartoznak: ${ }^{15}$

1. táblázat. A feledésbe $V$ 'elfelejtődik' szerkezetek elöfordulásai az MNSZ2-ben

\begin{tabular}{|c|c|}
\hline Feledésbe $\boldsymbol{V}$ & Gyakoriság \\
\hline borul & 2 \\
\hline enyészik & 1 \\
\hline homályosodik & 1 \\
\hline hull(ik) & 5 \\
\hline kerül & 16 \\
\hline megy & 227 \\
\hline merül & 2077 \\
\hline múlik & 1 \\
\hline oszlik & 1 \\
\hline süllyed & 10 \\
\hline süpped & 1 \\
\hline szitál & 1 \\
\hline tünik & 5 \\
\hline vész/veszik & 16 \\
\hline
\end{tabular}

Az egyes kifejezésekre kapott találati listákból minden esetben eltávolítottam mind az ismétlődő példákat, mind pedig a hibás találatokat - vagyis az 1. táblázatban szereplő gyakorisági adatok nem az MNSZ2 automatikus elemzéseinek eredményeire

${ }^{15}$ Gyakoriságon adott esetben a vizsgált nyelvi egységek adott korpuszon belüli előfordulásainak a számát értem. Az előfordulások kis száma miatt ez esetben relatív gyakoriság számolására nincs mód. 
épülő adatok számát, hanem a különböző igékkel alkotott szerkezeteknek a korpuszon belüli valós gyakoriságát mutatják.

Látható ugyanakkor az is, hogy a vizsgált szinonimakörhöz tartozó 14 szerkezet közül hat hapaxnak tekinthető - vagyis az adott korpuszon belül csupán egyszer adatolható -, ${ }^{16}$ és mindössze két kifejezés (a feledésbe merül és a feledésbe megy) fordul elő viszonylag nagy gyakorisággal a korpuszban. A szinkrón gyakorisági adatok alakulásának értelmezésére és az ezen adatokból levonható következtetések megfogalmazására a dolgozat 6 . alpontjában, a feledésbe $V$ 'elfelejtődik' szinonimakör szerveződését vizsgálva térek vissza részletesen. A következö, 4. és 5. alpontban, a felejtés lehetséges nyelvi megjelenítési módjait, illetve a szinonim feledésbe $V$ 'elfelejtődik' szerkezetek szemantikai sajátosságait tárgyalva azonban az egyes szerkezetvariánsok előfordulási gyakorisága közötti különbségeket - mivel az említett két alpontban felmerülö kérdések szempontjából ezek az eltérések nem relevánsak - nem veszem figyelembe.

\section{A felejtés nyelvi megjelenítésének lehetséges módjai}

\subsection{Emlékezés és felejtés}

Az emlék összefüggő hálózatokba szerveződő, szubjektív asszociációkkal összefonódó reprezentáció arról, amit megélünk - feldolgozott, előhívható, de közvetlenül, fizikai értelemben nem megragadható entitás, amelynek felidézése vagy elfelejtése nyelvileg csak metaforikus kifejezések segítségével tehető hozzáférhetővé. Az emlékezetkutatások ${ }^{17}$ jelenleg kísérletekkel alátámasztott, bár minden kétséget kizáróan nem bizonyított feltételezésként fogadják el, hogy az események emlékei a feldolgozáskor részekre bomlanak, az egyes részek, részletek pedig mintegy szétszóródnak az agykéregben - az érzékelés révén más-más agyi területeken hagynak nyomot -, majd az előhívás, felidézés során a hippokampusz a szétszórt részek egységbe rendezésével állítja össze újra a teljes emléknyomot. Mivel azonban a résztvevők, illetve a megfigyelök soha nem a maga objektív egészlegességében dolgozzák fel az egyes (átélt, illetve megfigyelt) eseményeket, valamint tipikusan a feldolgozás és a tárolás során is elvesznek bizonyos részletek az egyes emlékekből, az emléknyomok szükségszerüen hiányosak - ahhoz, hogy mégis egységes emlékképpé formálódjanak, arra van szükség, hogy az emlékezet további, az adott esemény felidézhető részleteinek ismeretében valószínüsíthető részletekkel egészítse ki az emlékeket. Ez az utólagos, kreatív rekonstrukciós folyamat azonban azzal jár együtt, hogy az emlékek minden felidézés során módosulhatnak.

Felejtés neurológiai értelemben akkor következik be, amikor az emlékeket kapcsolódásaik révén megtartó neuronok visszatérnek a korábbi állapotukba - ez az emlékezési folyamat bármely szakaszában végbemehet, de szoros összefüggésben áll az egyes emlékek részletgazdagságával és (szubjektív) fontosságával.

${ }^{16}$ A hapaxok esetében különösen feltünő, hogy a kreatív igeválasztással a nyelvhasználók új mozzanato(ka)t állítanak a figyelem elöterébe (vö. 5. alpont), ami adott esetben a szinonimakör további kiterjedését, bővülését eredményezi.

${ }^{17}$ A fenti áttekintés során alapul vett munkák: Csépe-Győri-Ragó (szerk.) 2007; KnowltonSquire 1995; Squire 2004; Caygill 2010; Sutton-Harris-Barnier 2010. 
Tágabb, hétköznapi értelemben ugyanakkor - bár ez esetben nem egy már bizonyos mértékig rögzült emléknyom „,elbomlásáról” van szó - felejtésként értelmezhető az is, hogy a figyelem és a memória korlátaiból, illetve az észlelés szubjektív természetéből adódóan a megfigyelő az egyes eseményeknek szükségszerüen csak bizonyos részleteit és csupán egy adott nézőpontból dolgozza fel, miközben számos további részlet elveszik az észlelés és így a későbbiekben az emlékezet számára is.

A következőkben - a kutatás középpontjában álló feledésbe $V$ 'elfelejtődik' szerkezeteket tágabb összefüggések közé helyezve - azt vizsgálom meg, hogy tipikusan milyen (metaforikus) nyelvi kifejezések segítségével beszélhetünk az emlékezés és a felejtés egymást feltételező és egymástól elválaszthatatlan folyamatáról: miként és milyen nézőpontokból ragadhatók meg nyelvileg az adott jelenségek. Az alább felvázolt áttekintés elsősorban a különböző nyelvi megjelenítési módokban megmutatkozó jellegzetes szemléletmódok feltárására vállalkozik; nem törekszik teljességre, és nem célja, hogy az emlékezéshez, valamint a felejtéshez kapcsolódó valamennyi nyelvi kifejezést számba vegye.

\subsection{Emlékezés és felejtés a nyelvi kifejezések tükrében}

Az emlékezés, illetve a felejtés folyamatának jellegzetes nyelvi megjelenítési módjait elsősorban a Magyar nemzeti szövegtár korábbi korpuszára (MNSZ1) épülő Mazsola keresőeszközt alkalmazva, a következő lekérdezések segítségével igyekeztem összegyüjteni:

$$
\begin{aligned}
& \text { - } \text { alany }=\text { emlé } \\
& \text { - alany }=\text { emlékezet } \\
& \text { - alany = feledés } \\
& \text { - alany = felejtés } \\
& \text { - tárgy = emléket } \\
& \text { - emlékezet(é)ben + ige szerkezetek } \\
& \text { - emlékezet(é)böl + ige szerkezetek }
\end{aligned}
$$

Ezenkívül - mivel a Mazsola csupán igei szerkezetek listázására alkalmas, a szóban forgó jelenségek pedig nem kizárólag igei kifejezések segítségével ragadhatók meg nyelvileg - a találati listát kiegészítettem Domonkosi Ágnes (2006) tanulmányának példaanyagával, amely más kutatási célokkal és más szemléleti keretben, de ugyancsak az emlékezet metaforáit tekinti át, számos különböző forrásból (szótárakból és internetes keresők segítségével) gyüjtve az emlékezés folyamatára vonatkozó metaforikus nyelvi kifejezéseket.

A következőkben elöször az emlékekhez (4.2.1.) és az emlékezethez (4.2.2.), majd a felejtéshez (4.2.3.) kapcsolódó jellegzetes nyelvi kifejezéseket és az ezekben megmutatkozó sajátos szemléletmódokat tekintem röviden át. Ezek a kifejezések azonban - mint azt az alább bemutatott példasorok is szemléltetik - éppúgy nem különülnek el élesen egymástól, mint ahogyan az emlékezés vagy a felejtés fogalma sem tárgyalható önmagában: mind az adott jelenségek, mind pedig azok nyelvi megjelenítési módjai együtt, egymást feltételezve és egymással szoros összefüggésben válnak értelmezhetővé. 
Ezzel együtt a példák áttekintése és rendszerezése ${ }^{18}$ során körvonalazódó különböző - gyakran egymással összekapcsolódó, máskor azonban egymást kizáró szemléletmódok sem különálló kategóriákként, hanem együttesen mutatják meg, hogy tipikusan miként, milyen nézőpontokból konstruálhatók meg nyelvileg az emlékek, illetve az emlékezés és/vagy a felejtés folyamatai. Az itt bemutatott áttekintésnek nem célja, hogy számot adjon az adott metaforikus nyelvi kifejezésekhez hozzárendelhető fogalmi metaforákról: ${ }^{19}$ a kutatás nem a fogalmi összefüggések feltárására vállalkozik, hanem különböző nyelvi szerkezeteket, kifejezésmódokat vizsgálva igyekszik képet kapni arról, hogyan interpretálódnak az adott kifejezésekben a szóban forgó jelenségek.

\subsubsection{Az emlékek nyelvi megjelenítésének jellegzetes módjai}

Azok a vizsgált anyagba bekerült (rendszerint) konvencionális, kollokációszerü kifejezések, amelyek tartalmazzák az emlék szót (is), jellemzően nem csupán a megnyilatkozónak az egyes, egyéni emlékekhez füződő sajátos és szubjektív viszonyulásáról árulkodnak. Az ilyen szerkezeteket vizsgálva képet alkothatunk arról is, hogy milyen általános kategóriákba sorolhatók nyelvileg, illetve milyen általános tulajdonságokkal, sajátosságokkal ruházhatók fel - esetenként antropomorfizáltan megjelenítve - egyrészt a konkrét, egyedi emlékek, másrészt az emlékezés és a felejtés komplex, minden beszélö által megtapasztalt, ugyanakkor közvetlenül nem hozzáférhető folyamatai. A vizsgálatba bevont kifejezések tanúsága szerint az emlékek nyelvileg úgy ragadhatók meg, mint amelyek:

- élnek, mozognak, például: él/megelevenedik/feltámad egy emlék; eleven emlék, vmi elevenen él vki emlékeiben, felelevenit / feléleszt / életre kelt egy emléket; kibomlik, kibontakozik az emlék; rajzanak, zsonganak az emlékek;

- önálló (az emlékezőétől független) akarattal és gyakran ártó szándékokkal rendelkeznek, például: csal, kísért, ólálkodik, munkálkodik, beleszúr vkibe, belehasit vkibe egy emlék; elcsendesedik az emlék(e vminek);

- részben autonóm, ugyanakkor befolyásolható, kontrollálható entitások, például: emlékeket ébreszt, elöhív, elöcsal(ogat), bolygat, elhesseget, számüz (az emlékezetéböl);

- (a természeti erőkhöz hasonlóan) nem feltétlenül kontrollálhatók: képesek a felidéző személy emlékezési szándéka nélkül (vagy akár annak ellenére), spontán, feltartóztathatatlanul is megjelenni, például: feltör, felbuzog [a mélyböl], elöszivárog az emlékezetböl, felködlik, elögomolyog [a láthatatlanságból], felbolydul egy-egy emlék; elöntenek, elárasztanak, elboritanak vkit az emlékek; felvillan, felragyog, felfénylik valami (az emlékezetben);

${ }^{18} \mathrm{Az}$ itt bemutatott rendszerezés természetesen csak egy a számos lehetséges rendszerezési mód közül.

${ }^{19}$ Ezzel együtt nem követi Domonkosi (2006) fogalmi metaforákkal operáló rendszerezését sem, ám - más összefüggések közé helyezve - felhasználja annak egyes megállapításait a kategóriák körvonalazása során. 
- átvehetik az irányítást az emlékező felett, például: elragad, megrohan vkit az emlék, eluralkodnak vkin az emlékek; az emlék formál, hajt, gátol, köt, korlátoz, vezérel vkit;

- rögzülhetnek, stabilan beépülhetnek a memóriába, például: megragad vmi az emlékezetben;

- értékesek, például: emlékeket gyüjt, (meg)ôrzi az emlékeit / vkinek/vminek az emlékét;

- nehezek lehetnek, terhet jelenthetnek az emlékező számára, például: az emlékek súlya/terhe, nyomasztó, súlyos, nehéz emlékek, emlékeket cipel;

- továbbadhatók, például: emléket ajándékoz, átörökit;

- törődést igényelnek, például: ápolja, babusgatja, dédelgeti az emlékeit; ápolja/elhanyagolja vkinek/vminek az emlékét;

- módosíthatók, átalakíthatók, újraalkothatók, például: átalakítja, átgyúrja, átlakkozza, elrontja, bearanyozza, befeketíti, besározza vkinek/vminek az emlékét;

- sérülhetnek, károsodhatnak, például: emlékfoszlány, szétfoszló emlékek [mint a szövet], emlékszilánk [mint az üveg], emléktöredék, töredékes emlék;

- passzívvá válhatnak, például: megfagy, alszik egy emlék;

- nehezen megtalálhatóvá válhatnak, például: emléket előkotor, elöás, előbányászik (az emlékezetéböl), kutat, keres vmit (az emlékezetében);

- (hirtelen vagy fokozatosan, átmenetileg vagy végérvényesen) hozzáférhetetlenné válhatnak, pl. elhalványul, (meg)fakul, elmosódik, elhomályosul vmi (az emlékezetben) [mint egy kép; vö. emlékképek], kifakul az emlékezetböl.

Érdemes felfigyelni rá, hogy amíg a felsorolás első felében szereplő szerkezetek az emlékek és az emlékezet vagy az emlékezés folyamatait jellemzik, az utolsó négy kategóriához sorolt kifejezések az emlékek változásának, „viselkedésének” megjelenítésén keresztül a felejtés folyamatára utalnak, illetve a felejtés folyamatát ábrázolják valamilyen módon. Az ezen kifejezésekben megmutatkozó szemléletmódok közül több megjelenik az expliciten az emlékezethez (4.2.2.) és a felejtéshez (4.2.3.) kapcsolódó szerkezetek körében is.

\subsubsection{Az emlékezet nyelvi megjelenítésének tipikus módjai}

Az emlékezet - az emlékezet nyelvi elemet tartalmazó nyelvi kifejezések tanúsága szerint - nyelvileg tipikusan az emlékek egyfajta gyüjtőhelyeként (TARTÁLYként) vagy az emlékek megőrzéséért felelős eszközként jelenik meg, amely állhat az emlékező személy vagy közösség ${ }^{20}$ irányítása alatt, de akár szembe is szegülhet vele, önkényesen manipulálva vagy elrejtve az emlékeket. Vagyis az emlékezet:

${ }^{20}$ A felejtés nem csupán az egyén tudati müködéséhez kapcsolódó jelenség: a közösség, illetve a kollektív tudat szempontjából is értelmezhető (vö. 6.1.1.). Erre utal az is, hogy az MNSZ2 korpuszában az emlékezet gyakran közösségre utaló jelzőkkel (pl. nemzeti, kollektív, kulturális, társadalmi emlékezet) alkot kollokációt. Az MNSZ2-ből származó kollokációk listáját köszönöm Kugler Nórának. 
- (amennyiben erre alkalmas) tárolja az emlékeket, például: (az emlékezet) megtartja, (meg)örzi, elraktározza, illetve kilöki, kiveti magából, kirostálja az emlékeket; kihullik, kiesik vmi az emlékezetböl; vki elraktároz vmit az emlékezetében;

- (meghibásodásra hajlamos) gépezetként felelős az emlékek előhívásáért, például: müködik, kopik, berozsdáll az emlékezet;

- képes az emlékek manipulálására, módosítására (akár a felidéző személy szándékai és/vagy akarata ellenére is), például: az emlékezet kiszinezi, korrigálja, megszépiti, összerakja, szelektálja, kimerevíti az emlékeket; torzit;

- megbízhatatlan, nem lehet számítani rá, például: cserben hagy, megtréfál, játszik (vkivel), kalandozik, téved, megtéveszt, (meg)csal, becsap, hütlenkedik.

Az emlékezet müködésére vonatkozó nyelvi szerkezetek viszonylag kis számát feltehetően elsősorban az eredményezi, hogy csupán az emlékezet szót is magába foglaló kifejezések kerültek be a vizsgált anyagba - a szóban forgó jelenségek azonban nyelvileg éppúgy megkonstruálhatók az esetenként ugyancsak az emlékezetre utaló memória, fej, agy, elme, gondolat stb. fönevek segítségével is. Ezen kifejezések számbavételére a jelen vizsgálat nem vállalkozott.

\subsubsection{A felejtés nyelvi megjelenítésének tipikus módjai}

A felejtés folyamatát a feledés és a felejtés nyelvi elemet tartalmazó nyelvi kifejezések a következőképpen jelenítik meg: ${ }^{21}$

- aktív cselekvő, például: a feledés/felejtés gyógyírt hoz vmire, kozmetikáz vmit [egy emléket], bajtársiasan viselkedik, rombol;

- akadályozza a vizuális hozzáférést, például: a feledés homálya, ködbe/homályba veszö emlék, ködös emlék;

- vízszerü közegként körülfogja, magába (a maga mélyére) rejti, hozzáférhetetlenné teszi az emlékeket (BENT hely), például: feledésbe merül/süllyed vmi, elmos vmit a feledés;

- földszerü közeg (BENT hely), például: a feledés mocsara, feledésbe süpped vmi; eltemet/betemet vmit a feledés;

- lepelszerüen beborítja, elfedi az emlékeket (így téve őket az észlelés számára hozzáférhetetlenné), például: (be)borit, (be)takar, befed vmit a feledés; feledés borul vmire, a feledés fátyla borit vmit / borul vmire.

A felejtés fogalma önmagában, az emlékezés, illetve az emlékek fogalma nélkül tehát értelmezhetetlen: a feledés minden esetben az emlékek részleges vagy teljes, át-

${ }^{21}$ Természetesen a felejtésről sem csupán expliciten a felejtés/feledés szavakat alkalmazva lehet beszélni; számos más szerkezet, kifejezésmód is alkalmas lehet az adott folyamat nyelvi megjelenítésére. A jelen dolgozat keretein belül azonban - mivel az itt bemutatott kutatás nem a lehetséges konstruálási módok részletes, árnyalt és kimerítő leírására vállalkozik, hanem elsődlegesen a feledésbe $V$ 'elfelejtődik' szerkezetek vizsgálatára irányul - ezekkel nem foglalkozom. 
meneti vagy végleges hozzáférhetetlenné válásának, megszünésének folyamataként ragadható meg. Fontos azonban, hogy ezek az emlékek nem kizárólag konkrét személyekhez, életeseményekhez, jelenetekhez kötődő emléknyomok lehetnek, és nem csupán az egyén pszichológiai-neurológiai müködésével összefüggésben értelmezhetők; tág értelemben emléknek tekinthetők a szokások, a megszokott viselkedési mintázatok, az ismeretek és közösségi szinten a hagyományok, normák, kulturális sajátosságok is - így az ezektől való eltávolodás is megragadható felejtésként. Erre a kérdéskörre a 6.1.1. alpontban, az elfelejt(ödik) ige szemantikai jellemzőivel öszszefüggésben röviden még visszatérek.

A 4.2.2.-4.2.4. alpontokban felsorolt kifejezések az emlékezési, illetve felejtési folyamatokat különböző - bár esetenként egymással szorosan összefüggő - szemléleti keretekben, más-más nézőpontokból konstruálják meg nyelvileg, míg az emlékképekhez való tudati hozzáférés nyelvileg sok esetben vizuális észlelésként, a feledés pedig a vizuális észlelés akadályozottságaként vagy lehetetlenségeként jelenik meg.

A felsorolásokból látható emellett az is, hogy a jelen vizsgálat szúk értelemben vett tárgyát képező feledésbe $V$ 'elfelejtődik' szerkezetek egy olyan összefüggésrendszerbe illeszkednek, amely az emlékeket dologszerü jelenségek észleleteiként teszi megragadhatóvá, és nem az emlékezetből való kikerülésüket, hanem a feledésbe való bekerülésüket állítja a figyelem előterébe. Az ilyen típusú szerkezetek - másmás módokon (vö. 5.2. alpont) - arra helyezik a hangsúlyt, hogy az adott emlék, bár nem szünik meg létezni, a feledési folyamat során hozzáférhetetlenné vagy nehezen hozzáférhetővé válik.

\section{A feledésbe V'elfelejtődik' szerkezetek szinonímiája}

A feledésbe $V$ 'elfelejtődik' szinonimakört tehát - a 4.2.3.-ban említetteknek megfelelően - az 'eltünik, hozzáférhetetlenné válik [az emlék]' mozzanat tartja össze, amely a szinonimakör valamennyi kifejezésének jelentésében hangsúlyosan jelen van. Az egyes kifejezések azonban különböző specifikus módokon és a folyamat más-más sajátosságait elötérbe helyezve jelenít(het)ik meg a hozzáférhetetlenné válást.

Feltételezésem szerint az egyes igéknek a feledésbe $V$ 'elfelejtődik' konstrukcióban való megjelenését szerkezeti és szemantikai összefüggések, tényezők is támogathatják. Ilyen szerkezeti motiváció lehet például az, ha egy ige tulajdonképpeni jelentésében is viszonylag gyakran fordul elö - $b A$ ragos vonzatokkal - ezért az alábbi, 5.1. alpontban bemutatott vizsgálat annak feltárására irányul, hogy az egyes alapigék $^{22}$ vonzatkeretében milyen gyakran fordulnak elő (amennyiben elöfordulnak) - $b A$ ragos névszói elemek, illetve hogy ezen vonzatokkal az igék tulajdonképpeni jelentésükben is alkothatnak-e szerkezetet, vagy az együttes előfordulás csupán az igei jelentés metaforizálódásával válik lehetségessé. Ezt követően, az 5.2. alpontban a lehetséges szemantikai motivációkkal foglalkozom: arra keresem a választ, hogy

${ }^{22}$ Mivel ez esetben, az adott (rész)kutatás során a szerkezetben megjelenő (nem prototipikus) funkcióigéknek nem a funkcióigei jellege válik hangsúlyos, meghatározó jellemzővé, az 5. alponton belül ezekre az elemekre alapigékként hivatkozom. 
milyen jelentésbeli tényezők - általános és/vagy specifikus jelentésmozzanatok motiválhatják az igék belépését a feledésbe $V$ 'elfelejtődik' konstrukcióba, valamint bemutatom, hogy a különböző igék milyen sajátos nézőpontokból teszik hozzáférhetővé a feledés folyamatát, illetve a felejtés mely specifikus mozzanataira irányíthatják a figyelmet. ${ }^{23}$

\subsection{Az alapigék előfordulása a $\mathrm{V}+\mathrm{N}-b \boldsymbol{A}$ típusú szerkezetekben}

A feledésbe $V$ 'elfelejtődik' típusú szerkezetek által alkotott szinonimakörhöz az MNSZ2 korpuszadatai szerint összesen 14 kifejezés sorolható - vagyis 14 különböző igei elem léphet be az 'elfelejtődik' jelentésű feledésbe $V$ szerkezetbe (lásd az 1. táblázatot korábban, illetve alább a 2. táblázatot). Az alapigék egy része tulajdonképpeni jelentésében is együtt állhat $-b A$ ragos vonzatokkal (ezek tipikusan mozgásra utaló igék, pl. megy, süllyed), míg mások (pl. vész, tünik) csak metaforikus jelentésükben vagy a feledésbe $V$ kifejezésen kívül egyáltalán nem (pl. homályoso$d i k)$ jelenhetnek meg $\mathrm{V}+\mathrm{N}-b A$ típusú szerkezetekben. Az egyes igei elemeknek az MNSZ1 korpuszán ${ }^{24}$ belüli gyakoriságát a 2. táblázat első oszlopa adja meg, míg a második oszlopban szereplő számok a $\mathrm{V}+\mathrm{N}-b A$ szerkezetekben való előfordulások számát mutatják. (A találati listák következetes manuális elemzésére - részben a találatok esetenként rendkívül nagy száma, részben a listázhatóság korlátai [vö. 26. lábjegyzet] következtében - ez esetben nem volt lehetőség, tehát a táblázatban szereplő adatok az ismétlődéseket és a hibás elemzéseket is magukba foglalják.)

2. táblázat. A feledésbe $V$ 'elfelejtődik' alapigéinek gyakorisági adatai (Mazsola)

\begin{tabular}{|l|c|c|}
\hline & Összes elöfordulás & $\mathbf{V}+\mathbf{N}-b^{*}{ }^{*}$ \\
\hline borul & 1766 & 645 \\
\hline enyészik & 44 & 1 \\
\hline homályosodik & 20 & 0 \\
\hline hull(ik) & 2582 & 439 \\
\hline kerül & több mint 20000** & több mint 20 000 \\
\hline megy & több mint 20 000 & 11387 \\
\hline merül & 1306 & 574 \\
\hline múlik & 6291 & 24 \\
\hline
\end{tabular}

${ }^{23}$ A funkcióigés szerkezetek igei elemeinek variálódására épülő szinonímiáról röviden lásd még: Lanstyák 2019: 79-80.

${ }^{24}$ A kereséseket az adott igei vonzatkeretek listázására is alkalmas Mazsola keresőeszköz segítségével végeztem, amely az MNSZ1 korpuszára épül. Az alapigék vonzatkerettől független előfordulásai (amelyeket a táblázat első oszlopa szemléltet) természetesen az MNSZ2-ben is kereshetök, így azonban - mivel ez utóbbi korpusz számottevően nagyobb szövegmennyiséget tartalmaz, mint az MNSZ1 - az igék összes elöfordulása és az adott szerkezettípusban való megjelenéseik száma kevésbé volna összevethető egymással. 


\begin{tabular}{|l|c|c|}
\hline oszlik & 809 & 17 \\
\hline süllyed & 2254 & 346 \\
\hline süpped & 224 & 150 \\
\hline szitál & 164 & 9 \\
\hline tünik & több mint 20000 & 232 \\
\hline vész & 487 & 285 \\
\hline
\end{tabular}

* Mivel a lekérdezés annak feltárására irányult, hogy a feledésbe $V$ szerkezetbe való belépést motiválhatja, illetve támogathatja-e az egyes igéknek a más $\mathrm{V}+\mathrm{N}-b A$ típusú szerkezetekhez való kötődése, ez esetben a feledésbe vonzatot kizártam a keresésből.

** Amennyiben egy elem 20 000-nél többször fordul elő az MNSZ1 korpuszában, a Mazsola csupán az első 20000 előfordulást listázza, és nem tünteti fel az összes előfordulás számát.

A gyakorisági adatok azonban önmagukban csupán az együttes előfordulások arányának hozzávetöleges érzékeltetésére lehetnek alkalmasak; az igéknek az adott szerkezettípushoz füződő - szemantikai szempontból megalapozott - viszonyára vonatkozóan pusztán ezekből nem következtethetünk. Az alapigék V + N- $b A$ szerkezetekben való előfordulásait közelebbröl megvizsgálva, illetve szemügyre véve azt, hogy az egyes igék tipikusan milyen konkrét névszói elemekkel alkotnak ilyen típusú kifejezéseket a korpuszban, árnyaltabb képet kaphatunk az igék és a $-b A$ ragos vonzatok közötti lehetséges kapcsolatok természetéröl. A Mazsola által listázott $\mathrm{V}+\mathrm{N}-b A$ kifejezéseket áttekintve a következök állapíthatók meg:

A homályosodik és a múlik ige - a feledésbe homályosodik, illetve feledésbe múlik szerkezeteken kívül - gyakorlatilag nem fordul elő - $b A$ ragos vonzatokkal az MNSZ1 korpuszán belül. Bár a múlik ige esetében az automatikus elemzés 24 találatot adott (lásd 2. táblázat), a találatok közül 22 a kereső hibás elemzésének eredménye, így az N-bA elem csupán két példában tartozik közvetlenül a múlik-hoz - ám mindkét szövegrészletben a kicsibe múlik kifejezés fordul elő.

A táblázatban feltüntetett egyetlen enyészik $N-b A$ szerkezet névszói eleme a múltba - az ige jelentése tehát ebben az esetben is éppúgy metaforikus jelentésü, mint a feledésbe enyészik esetében.

A szitál ugyancsak ritkán áll együtt - $b A$ ragos névszóval a korpuszon belül, ez azonban adódhat abból is, hogy az ige önmagában sem túl gyakori a vizsgált anyagban. A táblázatban szereplö kilenc előfordulás közül egy vaktalálat, öt a 'vki vmibe szitálva beleszór vmilyen (porszerü) anyagot' jelentéskörbe tartozik, három pedig arra utal, hogy a szitáló eső, illetve köd valakinek az arcába/szemébe hullik. A szerkezet tehát - a feledésbe szitál-tól eltérően - mind a nyolc esetben valamilyen jól megragadható, konkrét fizikai mozgást fejez ki.

Az oszlik által jelölt folyamat rendszerint valamiféle (konkrét vagy metaforikus értelemben vett) távolodó mozgással jár együtt, az ige jelentése azonban - sem tulajdonképpeni, sem metaforikus szinten - nem a távolodást/helyváltoztatást teszi hangsúlyossá, hanem azt állítja a figyelem elöterébe, hogy egy egységböl, illetve egy egységként értelmezett entitásból (adott esetben az egység részeinek helyváltoztató mozgása következtében) több új, kisebb egység jön létre, miközben az ere- 
deti egység megszünik létezni (pl. két csoportba, pirosakra és feketékre oszlanak a résztvevők). ${ }^{25}$

A tünik és a vész viszonylag gyakran fordul elő V + N-bA szerkezetekben - bár feltételezhető, hogy a Mazsola által listázott kifejezések között (különösen a tünik esetében) nagy arányban fordulnak elő hibás találatok is. ${ }^{26}$ Feltünő ugyanakkor, hogy a - $b A$ ragos névszóval alkotott szerkezetek mindkét ige esetében egyértelmüen metaforikus jelentésü igei szerkezetek (pl. szemébe, figyelmébe tünik vmi; kárba, homályba, múltba, ködbe, semmibe vész vmi), amelyek nem utalnak konkrét, fizikai értelemben vett mozgásra. A vész rendszerint - a feledésbe vész-hez hasonlóan ezekben a kifejezésekben is a hozzáférhetetlenné válásra, illetve ezzel együtt valamiféle veszteségre utal.

A borul, a hull(ik), a merül, a süllyed és a süpped igék mindegyike száznál többször - tipikusan néhány százszor - áll együtt N-bA vonzattal. (A feledésbe $V$ kifejezésekre - ahogyan fentebb említettem - természetesen ebben az esetben sem kerestem rá.) Ezen igék esetében érdemes számba venni, hogy a Mazsola automatikus elemzése szerint mely - $b A$ ragos névszókkal kollokálódnak a legerősebben:

A borul különösen gyakran fordul elő a nyakába, láng(ok)ba, árokba, virágba, sötét(ség)be, gyászba, vérbe, homályba, árnyékba, tüzbe, vízbe, fénybe és kar(já)ba/kar(jai)ba névszói elemekkel. Ezek közül a nyakába, a karjába/karjaiba, a vízbe és az árokba borul kifejezések tényleges, konkrét fizikai értelemben vett mozgásra, helyváltoztatásra utalnak - bár az ige nem feltétlenül tulajdonképpeni jelentésében fordul elő bennük -, a többi kiemelt szerkezet pedig azt fejezi ki metaforikusan, hogy az adott entitást elborítja, (mintegy vízszerüen) körülfogja a névszó által megnevezett, tipikusan anyagként konceptualizált entitás.

A hullik esetében a Mazsola az öl(é)be, porba, homlok(á)ba, semmibe, nyak(á)$b a, a r c(a ́) b a$, szem(é)be, talajba, kosárba, vizbe, kútba és hóba névszókat listázza kiemelten gyakori vonzatokként. A semmibe hullik kivételével ez esetben minden kifejezés utalhat konkrét fizikai értelemben vett mozgásra - amellett, hogy a szerkezetek többsége (megfelelö kontextusban) metaforikusan is értelmezhetö.

A merül az álomba, homályba, vízbe, hallgatásba, gondolat(ok)ba/gondolat(ai)ba, olvasásba, beszélgetésbe, mélységbe, magába, gond(ok)ba, részlet(ek)be névszói elemekkel áll együtt a legnagyobb gyakorisággal. A felsoroltak közül a vízbe merül az egyetlen olyan szerkezet, amely fizikai értelemben vett mozgásra vonatkozik, illetve a mélységbe merül is utalhat tényleges helyváltoztató mozgásra (jellemzően szintén vízben való alámerülésre); más esetekben az állapotokat, tevékenységeket, mentális jelenségeket stb. megnevező névszói elem egyértelmúen jelzi, hogy a kifejezések kizárólag metaforikusan értelmezhetők.

${ }^{25}$ Az oszlik vonzatkeretében ugyanakkor tipikusan nem - $b A$, hanem - $r A$ ragos névszói elemek fordulnak elő: míg az oszlik N-bA kifejezésekre a Mazsola - a hibás elemzésekkel együtt 17 találatot ad, az oszlik N-rA szerkezetek 575-ször fordulnak elö az MNSZ1 korpuszában. (Például a csoport(ok)ra oszlik 85-ször, míg a csoport(ok)ba oszlik mindössze 7-szer adatolható.)

${ }^{26}$ Ezen feltételezés ellenőrzésére adott esetben nincs mód, mivel a Mazsola segítségével az összes találat közül csupán az első 20000 nyerhető ki a korpuszból; ugyanakkor a nagy elemszám miatt a teljes találati lista ismeretében sem volna lehetséges a több tízezer találat manuális elemzése. 
A süllyed a mocsárba, mély(ség)be, recesszióba, káoszba, anarchiába, földbe, szegénységbe, nyomorba, válságba, tengerbe, apátiába, [vmilyen] állapotba, sorba vonzatokkal fordul elő kiemelkedően gyakran. Miközben a mocsárba, mély(ség)be , földbe, tengerbe süllyed kifejezések konkrét helyváltoztató mozgásra is vonatkozhatnak (amellett, hogy metaforikus jelentésekkel is rendelkeznek), a felsorolt névszói elemek többsége egyértelmüen valamilyen negatív, illetve a korábbinál roszszabbnak, kedvezőtlenebbnek tartott állapotra - azaz egyfajta metaforikus értelemben vett „mélységre” - utal. Vagyis a N-bA süllyed szerkezetek az esetek jelentős részében kedvezőtlen(ként interpretált) állapotváltozást fejeznek ki.

A süpped a - $b A$ ragos névszók közül csupán a magába, a földbe, a homokba, a hóba és a sárba vonzatokkal áll együtt viszonylag gyakran a vizsgált korpuszon belül. Ebben az esetben tehát egyértelmüen a konkrét fizikai mozgásra utaló kifejezések vannak többségben; a felsoroltak közül a magába süpped az egyetlen olyan szerkezet, amely egyértelmüen és kizárólagosan metaforikusan értelmezhető.

A V $+\mathrm{N}-b A$ kifejezésekben néhány százszor adatolható borul, hull(ik), merül, süllyed és süpped igékhez képest a kerül és a megy mint általános jelentésű mozgásigék mind tulajdonképpeni, mind metaforikus jelentésükben kiemelkedő gyakorisággal, több mint tízezerszer jelennek meg az adott szerkezettípusban - ugyanakkor ez feltehetően nem csupán a mozgásigei jelentésükkel függ össze (vagyis azzal, hogy mindkét ige valahonnan valahová tartó mozgást fejez ki), hanem azzal is, hogy ezek az elemek a szóban forgó vonzatkerettől függetlenül is rendkívül gyakran fordulnak elö a korpuszban.

Mindezeket figyelembe véve megállapítható, hogy a tulajdonképpeni jelentésükben helyváltoztatásra utaló mozgásigék (pl. megy, süllyed) esetében a mozgásigei jelentés - amely feltételezi a valahová (valamibe vagy valami felé) való irányulást - nagymértékben hozzájárulhat ahhoz, hogy az adott elemek megjelenhessenek a $\mathrm{V}+\mathrm{N}-b A$ típusú szerkezetekben akkor is, ha a vonzat adott esetben metaforikus értelemben vett helyet (pl. állapotot) jelöl. Ezenkívül az is támogathatja egyes igéknek a feledésbe $V$ szerkezetben való elöfordulását, ha az adott, tulajdonképpeni jelentésében nem helyváltoztatásra utaló ige a feledésbe $V$ mellett számos más kifejezésben is metaforikus értelemben vett mozgásra (pl. állapotváltozásra, valamilyen állapotba való bekerülésre) vonatkozik (pl. vész). A szerkezeti motiváció önmagában azonban természetesen nem elégséges ahhoz, hogy két nyelvi elem összekapcsolódjon egymással: az igék és az igei vonzatok között bizonyos mértékü szemantikai kapcsolatnak is lennie kell.

A következő, 5.2. alpontban azt vizsgálom meg részletesebben, hogy a feledésbe $V$ 'elfelejtődik' szerkezetbe belépő különböző alapigék esetében miben áll, illetve hogyan ragadható meg ez a szemantikai kapcsolat, valamint - ezzel együtt - kitérek arra a kérdésre is, hogy az egyes igék milyen specifikus jelentésmozzanatokkal járulhatnak hozzá a szerkezet jelentéséhez, és milyen sajátos nézőpontokból teszik hozzáférhetővé a felejtés folyamatát. 


\subsection{Az alapigék szemantikai illeszkedése a feledésbe $V$ 'elfelejtődik' konstrukcióhoz}

A feledésbe $V$ 'elfelejtődik' konstrukció különböző variánsainak szemantikai sajátosságait elsősorban korpuszadatokra épülö, kvalitatív jelentéselemzések segítségével vizsgálom, de az adott jelentéseket meghatározó főbb mozzanatok körvonalazása során figyelembe veszem a magyar egynyelvű szótárak - különösen az ÉrtSz., az ÉkSz. ${ }^{1}$, az ÉKSz. ${ }^{2}$, valamint az Nsz. - meghatározásait és példaanyagát is.

Részletes, az MNSZ2 adataira épülő és a szerves nyelvelmélet (vö. pl. Zsilka 1978; NyMDK. 1-11) elemzési metódusait követő jelentéselemzést csupán a merül esetében végeztem. A vizsgált szinonimakör egyes szerkezeteiben előforduló további igéknek csupán az adott szerkezetben relevánssá váló jelentésmozzanatait igyekeztem feltárni részben a fent említett szótárak definícióit, részben pedig a Mazsola keresőeszköz találati listáin az igék vonzatkeretében megjelenő - $b A$ ragos névszók szemantikai csoportjait vizsgálva (vö. 5.1.) - hiszen ezen vonzatok alapján következtethetünk az ige egyes jelentéseit uraló föbb jelentésmozzanatokra is. ${ }^{27}$

\subsubsection{Mozgást kifejező igék}

A vizsgált szinonimakörhöz tartozó 14 kifejezés közül hatban olyan mozgásige jelenik meg, amely szerkezeti szempontból is egyértelmúen és jól illeszkedik a $\mathrm{V}+\mathrm{N}-b A$ sémát követö feledésbe $V$ szerkezetbe (vö. 5.1.). Ezek közül négy (hullik, merül, süllyed, süpped) tulajdonképpeni jelentésében lefelé irányuló mozgásra utal, míg kettő (megy, kerül) ilyen értelemben nem specifikálja a mozgás irányát, sem pedig más jellegzetességeit.

\section{A) Általános jelentésű mozgásigék}

Mind a kerül, mind a megy általános jelentésü mozgásige, amelyek egyik legkarakteresebb szemantikai sajátossága az adott szerkezetekben éppen az, hogy általános szinten, mintegy semleges nézőpontból ragadják meg - tehát nem specifikálják és nem értékelik - a felejtés folyamatát. Fontos különbség azonban közöttük, hogy a kerül passzivitást és szándéktalanságot, míg a megy aktivitást és az emléket elfelejtő személytől való távolodást implikál. A feledésbe kerül igei eleme nemcsak az emlékeket elfelejtő személyt, hanem az elfelejtődő emléket is a folyamat passzív résztvevőjeként, elszenvedőjeként ábrázolja: azt fejezi ki, hogy a feledés egyszerüen csak megtörténik, spontán végbemegy. Ezzel szemben a megy az elfelejtődő emléket tudatos, saját akarattal rendelkező cselekvőként, a folyamat aktív résztvevőjeként jeleníti meg, ,aki” mintegy szándékosan távozik a feledésbe.

${ }^{27}$ Mivel a lineáris sor egyes elemeinek jelentései között szoros kölcsönhatások feltételezhetők (vö. pl. Zsilka 1982; funkcionális kognitív nyelvelméleti elméleti keretben: Langacker 1987), az igével szerkezetet alkotó vonzatok utalhatnak a velük együtt álló igei elem jelentésrendszerének, illetve adott jelentéseinek sajátosságaira is. Az igék mellett vonzatként megjelenő névszók rendszerint viszonylag jól körülhatárolható, közös(ként értelmezett) jelentésmozzanat(ok) által összetartott szemantikai csoportokba rendezhetők, amely csoportok körvonalazása hozzájárulhat az igei jelentések föbb mozzanatainak feltárásához (vö. Hrenek 2019b). 


\section{B) Lefelé irányuló mozgásra utaló igék}

Az, hogy a feledésbe $V$ 'elfelejtődik' szerkezetek körében viszonylag nagy arányban fordulnak elő tulajdonképpeni jelentésükben specifikusan lefelé irányuló mozgást kifejező igék, feltehetően azzal hozható összefüggésbe, hogy a) a konkrét, fizikai értelemben lefelé tartó mozgás gyakran negatív következményekkel (pl. sérüléssel, károsodással) jár együtt, vagyis valamilyen kedvezőtlen állapotváltozással kapcsolódik össze (vö. A LENT ROSsz, Kövecses 2005: 254), valamint hogy b) ugyancsak a konkrét fizikai tapasztalatok szerint, ami mélyre kerül, elsüllyed vagy elmerül (pl. a víz mélyére vagy adott esetben például a tudatalattiba mint LENT helyre jut), az az észlelés, illetve a tudat számára hozzáférhetetlenné válik; eltünik a megfigyelö személy elől. Az itt említhető feledésbe $V$ szerkezetek igei elemeinek esetében úgy tünik, hogy ha az ige tulajdonképpeni jelentésében esési folyamatra vonatkozik (hullik), vagyis azt fejezi ki, hogy valamely dologszerü entitás egy térben magasabban lévő pontról egy alacsonyabban lévő pontra jut, az adott ige az adott metaforikus jelentésében is elsősorban a negatív irányú állapotváltozás kifejezésére - illetve az adott állapotváltozás negatívként való értékelésére - válik alkalmassá, míg a tulajdonképpeni jelentésükben víz- vagy mocsárszerü közegben való alámerülésre utaló igék (merül, süllyed, süpped) adott metaforikus jelentésükben is az 'eltünik, hozzáférhetetlenné válik' mozzanatot emelik ki. Ugyanakkor, ha a feledésbe $V$ szerkezeteket egységként szemléljük, természetesen nem tekinthetünk el attól sem, hogy a névszói elem jelentéséből adódóan a feledésbe hullik is egy adott közegbe való bekerülésre, illetve az abban való alámerülésre is utal.

A hullik ige legkarakteresebb specifikuma mindezekkel együtt alapvetően nem a felejtés negatív eseményként való értékelése, hanem az, hogy - mivel az ige jelentésrendszerének hangsúlyos mozzanata a 'nagy mennyiségben', illetve a 'folyamatosan' mozzanat ${ }^{28}$ - ez az elem fokozatosan végbemenő folyamatként jeleníti meg a felejtés folyamatát, amelynek során az egyes emlékek, illetve egy emlék egyes részletei egymás után válnak hozzáférhetetlenné. Az emlék(ek) hozzáférhetetlenné válására - ahogyan erre fentebb is utaltam - az ige önmagában nem utal; ez a mozzanat adott esetben a névszói elemnek, illetve a szerkezet egészének mint egységnek a jelentéséből adódik.

A merül (vö. 6.3.) is fokozatos és viszonylag lassú folyamatként ábrázolja a felejtést, ám - azzal együtt, hogy tulajdonképpeni jelentése révén az adott jelenetet a vízben (vagy valamely más, a víznél sủrübb anyagban) való alámerüléshez teszi hasonlóvá - a mélyre kerülést, illetve az ebből következő eltűnést, hozzáférhetetlenné válást állítja a figyelem előterébe. A feledésbe merül kifejezés mint egység - ugyancsak a vízben való elmerülés képzetével összefüggésben - a feledést (mint

${ }^{28}$ Vö. például hullik az esö, a hó, a por, a homok; hullanak a csillagok; hullik a haja, a tolla; ezenkívül azt, hogy a 'nagy mennyiségben' mozzanat valóban releváns az ige jelentésrendszerében, például a hull(ik) a vére/könnye kifejezések is alátámasztják. (A 'nagy mennyiségben' mozzanat a különböző jelentésekben, illetőleg a különböző névszókkal alkotott szerkezetekben más-más módokon specifikálódhat; a jelentésmozzanatok változásának, változatainak kérdésére azonban a jelen dolgozat keretében nincs mód részletesen kitérni.) 
tartályszerü BENT helyet) valamiféle puha, laza, ugyanakkor bizonyos mértékü ellenállást is kifejtő, a benne való elmerülést mintegy lefékező, fokozatossá lassító közegként ragadja meg, amely körülfogja, elborítja, és ilyen módon teszi hozzáférhetetlenné, illetve manipulálhatatlanná az egyes emlékeket.

A süllyed adott jelentése közel áll a merül jelentéséhez, hiszen alapvetően mindkét ige a vízben (vízszerü közegben) való mélyre kerüléssel hozza kapcsolatba az emlékek elfelejtését; fontos különbség azonban, hogy a süllyed implicit értékelést is hordoz: romlásként, nemkívánatos állapotváltozásként értékeli a folyamatot. ${ }^{29}$ A metaforikus értelemben vett mélység, illetve a 'mélyre kerülés', mozzanata a süllyed jelentésrendszerén belül tehát nem az 'elkülönülés', mozzanatával fonódik össze - mint a merül esetében -, hanem a mélység negatív állapotként való konceptualizálásával összefüggésben értelmezhetö.

A süpped a sárban, illetve a mocsárban való elmerülés képzetével kapcsolja öszsze a felejtés folyamatát. Ugyancsak viszonylag lassú és fokozatos - nem feltétlenül teljes - alámerülési folyamatra utal, ami adott esetben a közeg nagyobb ellenállásából adódik.

\subsubsection{Mozgásra is utaló, de nem a helyváltoztatás mozzanatát kiemelő igék}

A borul, a szitál [pl. az eső / a köd] és az oszlik igék tulajdonképpeni jelentésükben olyan folyamatokat jelölnek, amelyek mozgással - tipikusan helyváltoztatással - járnak együtt, azonban ezek az igék mégsem elsősorban a térben történő elmozdulást fejezik ki. A mozgás az adott folyamatok inherens, szükségszerü velejárója, de tipikusan sem a folyamatok észlelésekor, sem pedig azok nyelvi megjelenítése során nem erre a mozzanatra irányul a figyelem. A szóban forgó igék mindegyike előfordulhat - a feledésbe $V$ szerkezeten kívül is - V + N-bA típusú szerkezetekben, az ilyen használatok aránya azonban csupán a borul esetében tekinthető számottevőnek (vö. 5.1.).

A borul - amelynek jelentésrendszerét a mozgásigékhez hasonlóan a 'jut [vmi vhová]' általános mozzanat határozza meg (vö. pl. a kocsi az árokba / a cukor az asztalra borul) - szorosan kötődik az 5.2.1.-ben említett (lefelé irányuló) mozgást kifejező igék csoportjához is, mivel azonban komplexebb folyamatokat jelenít meg, mégsem tekinthető szük értelemben vett mozgásigének. A feledésbe borul szerkezetben az ige jelentésének 'eltakar, befed' mozzanata kerül előtérbe. ${ }^{30} \mathrm{Az}$ ige a feledést hirtelen végbemenő folyamatként ábrázolja, és úgy jeleníti meg, mintha valamely

${ }^{29}$ Vagyis az ige metaforikus jelentésében is lefelé irányuló - adott esetben azonban nem tényleges, fizikai értelemben vett, hanem metaforikus - mozgásra utal, és ilyen módon jelenít meg kedvezőtlen irányú állapotváltozást. (Ezzel együtt nagy arányban fordul elő negatív állapotokra utaló névszókkal, pl. recesszióba, anarchiába, káoszba, szegénységbe, válságba, apátiába süllyed [Mazsola]; vö. 5.1.) Kognitív nyelvészeti keretben ez a jelenség A LENT Rossz orientációs metaforával összefüggésben értelmezhetö.

${ }^{30}$ Az ige jelentésének ez az 'eltakar, befed' mozzanata - illetve ezen mozzanat valamely variánsa (vö. 28. lábjegyzet) válik hangsúlyossá például a sötétség borul vmire, a gyászba borul vagy a virágba borul metaforikus kifejezésekben is. (A borul szóban forgó jelentéseinek értelmezéséhez a borul : borit oppozíciót is szükséges tekintetbe venni - például virágok boritják / a virágok beboritják a fát a fa virágba borul -, ezeket az összefüggéseket azonban a jelen kutatásban nem vizsgáltam részletesen.) 
anyagszerủen konceptualizálódó entitások a dologszerüen konceptualizálódó emléket körülvennék, teljes mértékbe beburkolnák, és ezáltal hozzáférhetetlenné tennék.

A szitál - a hullik-hoz hasonlóan - a felejtés lassú és fokozatos voltára helyezi a hangsúlyt, utalva egyúttal arra is, hogy a folyamat során az emlék apró részei, részletei sorra kerülnek ki az emlékezetből (illetve kerülnek be a feledésbe).

Az oszlik - ahogyan erre az 5.1.-ben is utaltam - az egység, vagyis adott esetben az egységes egésznek tekintett emlékkép felbomlását fejezi ki, a feledést pedig ezzel a felbomlási folyamattal azonosítja.

\subsubsection{Veszteségre, elmúlásra utaló igék}

A szinonimakörhöz sorolt kifejezések közül ötben olyan ige fordul elö, amely a veszteség és/vagy az elmúlás fogalma felől ragadja meg, és ezzel együtt értékeli is a feledési folyamatot; ezek: az enyészik, a vész, a tünik, a múlik, valamint a homályosodik. Ezek az igék tulajdonképpeni jelentésükben egyáltalán nem és többségükben metaforikus jelentéseikben sem gyakran fordulnak elő $\mathrm{V}+\mathrm{N}-b A$ típusú kifejezésekben. ${ }^{31}$

Az enyészik és a vész pusztulásként - az emlékek pusztulásaként, megsemmisüléseként -, illetve veszteségként ábrázolja a felejtést, és a negatív következményre helyezve a hangsúlyt magát a folyamatot is egyértelmúen negatívként értékeli.

A tünik és a múlik igék az elmúlásra utalnak, és ezzel együtt ugyancsak bevonják az értelmezésbe a veszteség képzetét is, de (az enyészik-hez és a vész-hez képest) kevésbé teszik hangsúlyossá a megnyilatkozó negatív értékelését, illetve negatív attitüdjeit. A felejtés folyamatát az eltünés, felszámolódás felöl, a volt és a nincs kettősségében ábrázolják.

A homályosodik ige csak részben és áttételesen sorolható a veszteséget, illetve a negatív értékelést kifejező igék közé, hiszen nem tartalmazza inherens jelentésmozzanatként a szóban forgó mozzanatokat. A feledésbe homályosodik egyértelmüen hapax, amely a feledésbe merül és az elhomályosodik kifejezések vegyüléséből, egymásba játszásából létrejövő úgynevezett pregnáns kifejezésként (vö. pl. J. Soltész 1959: 59) értelmezhetö. Kialakulásában ugyanakkor szerepet játszhatott a feledés ködébe vész és a feledés homályába vész szerkezet is, amelyek a feledést expliciten alaktalan, körvonalak nélküli, homályos helyként jelenítik meg, és egyúttal azt is kifejezik, hogy a(z ilyen módon) feledésbe kerülö emlékek nem lesznek teljes mértékben hozzáférhetetlenek, csupán nagymértékben akadályozottá válik az előhívásuk. Ezzel összhangban a feledésbe homályosodik is inkább nehezített előhívásra, mintsem teljes feledésre vonatkozik, miközben utal a korábban élénk, eleven, éles körvonalakkal rendelkező emlékképek megfakulására is. A felejtést lassú, fokozatos és csupán részlegesen végbemenő folyamatként ábrázolja.

${ }^{31}$ Ugyanakkor meg kell jegyezni, hogy a vész több különböző metaforikus jelentésü $\mathrm{V}+\mathrm{N}-b A$ kifejezésben is felvehet a feledésbe vész-ben megfigyelhetöhöz hasonló jelentést (pl. homályba, semmibe vész), valamint hogy a tünik igétől sem idegen az ilyen típusú szerkezetekben való elöfordulás - bár ez utóbbi ige elsősorban észlelésre vonatkozó kifejezésekben állhat együtt - $b A$ ragos vonzatokkal (pl. szemébe/figyelmébe tünik vkinek vmi). 


\section{A vizsgált szinonimakör szerveződése}

\subsection{A feledésbe $V$ 'elfelejtődik' és az elfelejtődik viszonya}

A funkcióigés szerkezetek a velük szinonim (és a szerkezet(ek) névszói elemével morfológiailag is rokon) igével összefüggésben értelmezhetők, illetve jellemezhetők (vö. 1.). Ezenkívül az egyes konstrukcióvariánsoknak a szinonimakörön belül elfoglalt pozíciójára is hatással lehet (vö. 6.3.) az a tényezö, hogy az adott variáns szemantikailag és/vagy használati körét tekintve milyen viszonyban áll a szinonim igével.

A felejtés folyamatára tipikus esetben az elfelejt mediális ige utal, amely személyhez kötötten, alapvetően azonban a szóban forgó személy szándékaitól, akaratától független történésként jeleníti meg az adott folyamatot (vö. pl. Forgács 1998: 305). (Szemben például az emlékezik igével, amely tudatos cselekvést feltételezve az emlékek akaratlagos felidézésére vonatkozik.) Ehhez a konstruálási módhoz képest mind a mediopasszív elfelejtödik, mind a funkcióigés feledésbe $V$ 'elfelejtődik' konstrukció specifikusnak tekinthetö. A funkcióigés szerkezetek azonban az elfelejtödik-kel összevetve - ahogyan ezt az alábbiakban felvázolt adatok is alátámasztják - sem használati gyakoriságukat, sem szemantikai komplexitásukat tekintve nem másodlagosak.

\subsubsection{Az elfelejtődik szemantikai és pragmatikai sajátosságai}

Az elfelejtödik ige (szótöként) mindössze 567-szer ${ }^{32}$ fordul elö az MNSZ2 korpuszában - szemben például a feledésbe merül-lel, amelyre 2077 találat van, illetve a korpuszban összesen 29 838-szor szereplö elfelejt igével. Az elfelejtödik alacsony gyakorisága feltehetően azzal függ össze, hogy ez az ige a) mediopasszív igeként (a felejt igétől eltérően) sajátos, nem tipikus nézőpontból konstruálja meg a felejtés folyamatát, valamint b) sajátos megnyilatkozói attitüdöket implikál(hat).

Modrián-Horváth (2020) a passzív szerkezetek jellemzőjeként említi - többek között - az átperspektiválást, az ágens-defókuszálást és azt, hogy ezek a kifejezések elsődlegesen valamely nem ágensi résztvevőre irányítják a figyelmet. Az elfelejtődik-kel, illetve a felejtési folyamattal mint történéssel összefüggésben ágensről természetesen nem beszélhetünk, a(z elfelejt használatához képest értelmezett) perspektívaváltás azonban az elfelejtődik esetében is megfigyelhetö, és ezzel együtt megfigyelhetö az is, hogy az elfelejt [vki vmit] szerkezet elsődleges figurája - a felejtési folyamat experiense - háttérbe kerül, helyette pedig az elfelejtett/elfelejtődő emlékre mint páciensre kerül a hangsúly. Az elfelejtődik igét tartalmazó szerkezetekben az experiens-defókuszálás azonban gyakran csupán látszólagos, és tipikusan pragmatikai okai vannak. A sok esetben konkrétan a tágabb szövegkörnyezetben sem megnevezett, ugyanakkor a szövegösszefüggések / a kontextus ismeretében könnyedén kikövetkeztethető experiens - egyén vagy csoport, illetve közösség - az MNSZ2 adatainak tanúsága szerint általában

- valaki, aki gondolt, érzett, tudott valamit, amit már nem gondol, érez, tud;

- valaki, akinek a feladata, felelőssége lett volna, hogy egy el nem intézett ügy elintéződjön;

${ }^{32}$ Az automatikus keresés 692 találatot ad, ebből azonban 125 előfordulás ismétlődés vagy vaktalálat. 
- valaki, aki megígért valamit, ami a későbbiekben nem teljesült;

- valaki, akinek meg kellett volna tennie valamit, amit nem tett meg;

- valaki (tipikusan vitapartner), aki nem vesz figyelembe vagy nem fogad el valamit, ami a megnyilatkozó interpretációja szerint fontos;

- valaki vagy valamely csoport, aki/ami tudott vmiröl / ismert vkit, de egy idő után már nem vett róla tudomást;

- az a tágabb közösség (beszélöközösség, köztudat, közvélemény stb.), amely a kollektív emlékezetet müködteti/müködtethetné, de nem teszi;

- az a közösség, amely követhetné a közösség életében korábban fontos szerepet betöltő (pl. nyelvi, viselkedési, erkölcsi) normákat, illetve továbbvihetné a közösségformáló szokásokat, hagyományokat, de nem teszi.

Elfelejteni tehát nem csupán szük értelemben vett emlékeket, illetve információkat, gondolatokat vagy feladatokat lehet: ${ }^{33}$ éppígy elfelejthetők az érzések, a hiedelmek, a valamihez füződő attitüdök/viszonyulások, a képességek (pl. elfelejtett biciklizni 'elfelejtette, hogyan kell biciklizni', elfelejtett spanyolul), szokások, viselkedésmódok stb. is. ${ }^{34}$

Ugyanakkor mivel az elfelejtődik ige nem ágenst, hanem experienst feltételez, és a szóban forgó személy helyett látszólag az elfelejtődő dolgot állítja a figyelem előterébe, ez a kifejezésmód alkalmas lehet arra is, hogy segítségével a megnyilatkozó indirekt és implicit, ugyanakkor a befogadó számára viszonylag jól értelmezhető módon fejezzen ki negatív attitüdöket, kritikát, számonkérést vagy éppen szemrehányást.

Az elfelejtődik ezenkívül utalhat valakinek vagy valaminek a figyelmen kívül hagyására is. Ekkor az ige ugyancsak azt implikál(hat)ja, hogy a megnyilatkozó interpretációja szerint nem szándékos ignorálásról, csupán véletlenül végbemenő felejtési folyamatról van szó. Amennyiben az konstruálódik meg elfelejtődésként, hogy valaki - bármilyen okokból következően, illetve szándékosan vagy szándéktalanul - figyelmen kívül hagy egy, a megnyilatkozó által lényegesnek vélt szempontot, információt, érvet (stb.) például a döntése vagy egy vita során, az elfelejtődik egyúttal azt is sugallhatja (gyakran manipulatív módon vagy ironikus megnyilatkozás részeként), hogy az adott tényező kizárólag véletlenül kerülhette el az említett személy figyelmét, miközben a szóban forgó információ hitelessége, hozzáférhetösége, relevanciája, fontossága megkérdőjelezhetetlen előfeltevésként értelmeződik.

A korpuszadatok ugyanakkor mindezekkel együtt is arra engednek következtetni, hogy - bár mediopasszív igeként sajátos, nem tipikus konstruálási módnak tekinthető, és (ettől nem függetlenül) használatának erőteljes pragmatikai motivációi

${ }^{33}$ Az elfelejtődik ige csupán néhány példában utal egyértelmüen valamely eseményemlékek vagy emlékképek elfelejtésére.

${ }^{34}$ Itt érdemes megemlíteni, hogy pszichológiai-neurológiai értelemben sem csupán a korábban átélt események reprezentációi tekinthetők emlékeknek. A deklaratív-szük értelemben vett - emlékezet körébe tartozó „tudom” típusú, ismeretekre vonatkozó emlékek (szemantikus emlékezet), valamint az „emlékszem” típusú eseményemlékek (epizodikus emlékezet) mellett tág értelemben emlékekként foghatók fel azok a procedurális (nem deklaratív) emlékezethez kötődő szokások, készségek, szabályok is, amelyek automatizmusokban és a mindennapi viselkedésmódokban nyilvánulnak meg (vö. pl. Knowlton-Squire 1995). 
is lehetnek - az elfelejtödik jelentése sem az elfelejt, sem pedig a feledésbe $V$ 'elfelejtődik' szerkezetek jelentéséhez képest nem tekinthető specifikusnak. Szemantikai szempontból ez az ige tehát a vizsgált konstrukcióvariánsok közül a rendkívül általános jelentésü igét tartalmazó feledésbe kerül kifejezéshez áll a legközelebb.

Mindez alátámasztja azt az 1. alpontban (az ige szemantikai sajátosságai alapján elkülönülő típusokkal összefüggésben) röviden már említett feltételezést, amely szerint minél specifikusabb a szerkezetben megjelenő funkcióige jelentése, annál nagyobb a távolság az adott funkcióigés szerkezet és a vele szinonim ige jelentése között. (Hiszen a specifikusabb jelentésű funkcióigék több olyan specifikus jelentésmozzanattal járulnak hozzá a szerkezet jelentéséhez, amely mozzanatok a szinonim ige jelentésének nem részei, vö. például kérdez vs. kérdésekkel bombáz $\supset$ 'gyors egymásutánban', 'sokszor', 'fenyegetően'.) Illetve másfelöl: hogy az általánosabb jelentésủ igét tartalmazó kifejezések szemantikailag közelebb állnak a szerkezettel szinonim igéhez, mint a specifikusabb jelentésüek.

\subsubsection{A feledésbe $V$ 'elfelejtődik' szerkezetek és az elfelejtödik ige}

A feledésbe $V$ 'elfelejtődik' típusú szerkezetek főbb jellegzetességeit (vö. 5. alpont), valamint az elfelejtödik használatának sajátosságait (vö. 6.1.1.) áttekintve megállapítható, hogy az analitikus kifejezésmód(ok) és a szintetikus kifejezésmód kapcsolata adott esetben sokkal komplexebb viszony annál, mint amit a szakirodalom jelentős része - és különösen a szakirodalom egy részére nagy hatást gyakorló nyelvmüvelö szemléletü írások többsége - a funkcióigés szerkezetek és a velük szinonim igék között feltételez (pl. Keszler 2000; Hegedűs 2004; Forgács 2007, 2015). ${ }^{35}$ Ezzel együtt kijelenthetö, hogy a feledésbe $V$ kifejezések igei elemei minden esetben valamilyen sajátos jelentésmozzanattal árnyalják a szinonimakört összetartó 'elfelejtődik' jelentést, és így nemcsak a folyamatra magára, hanem annak módjára, körülményeire is utalhatnak, valamint kifejezhetik a megnyilatkozónak az adott eseményhez füződő attitüdjeit. ${ }^{36}$ Feltehetően az esetek jelentős részében éppen ezek a jellegzetességek motiválják a funkcióigés szerkezetek használatát.

A szinonim elfelejtödik ezzel szemben szemantikai szempontból nem specifikus, ám sajátos pragmatikai funkciók kapcsolódnak a használatához, így ez a kifejezésmód is alkalmas arra, hogy impliciten utaljon a megnyilatkozó attitüdjeire. (Ezek a jellemzően negatív attitüdök azonban szinte minden esetben a valamit elfelejtő vagy figyelmen kívül hagyó személyre vonatkoznak, míg a funkcióigés szerkezetek inkább a megnyilatkozónak a folyamathoz való viszonyulásáról árulkod(hat)nak.)

A kétféle kifejezésmód között ugyanakkor nemcsak különbségek, hanem hasonlóságok is megfigyelhetők, hiszen a felejtést - a szokásosan, illetve szélesebb

${ }^{35}$ A viszony komplexitására - részben más nézőpontból és a funkcióigés szerkezetek fogalmát az itt alkalmazott értelmezésnél tágabban értve - Dobos Csilla (2009: 35-42) és Lanstyák István (2019) is felhívja a figyelmet.

${ }^{36}$ Ez bizonyos mértékig még az általános jelentésü feledésbe kerül szerkezetre is igaz, hiszen ez a kifejezésmód éppen attól válhat sajátossá, hogy a konvencionális feledésbe merül-höz (vö. 6.2., 6.3.) képest általánosabb szinten, mintegy hangsúlyozottan semleges nézőpontból jeleníti meg az adott folyamatot. 
körben használt elfelejt-tel ellentétben - mindkét nyelvi megoldás a szóban forgó személy akaratától hangsúlyozottan független, nem szándékos, spontán végbemenő eseményként konstruálja meg. Ezzel együtt az experiens - látszólag vagy ténylegesen - háttérbe szorul, és gyakran implicit marad (vagyis experiens-defókuszálás történik, vö. Modrián-Horváth 2020), míg a páciens elötérbe kerül: nem a személy, hanem az elfelejtődő dolog, emlék áll a középpontban. (Ez esetenként olyan módon is megvalósulhat, hogy az adott emlék antropomorfizáltan, tudatos, távolodó mozgást végző cselekvőként jelenik meg a nyelvi kifejezésben, vö. pl. feledésbe megy.)

Az ige és az igei szerkezetek közös, illetve eltérő jellemzőit összefoglalóan az alábbi, 2. ábra tekinti át:

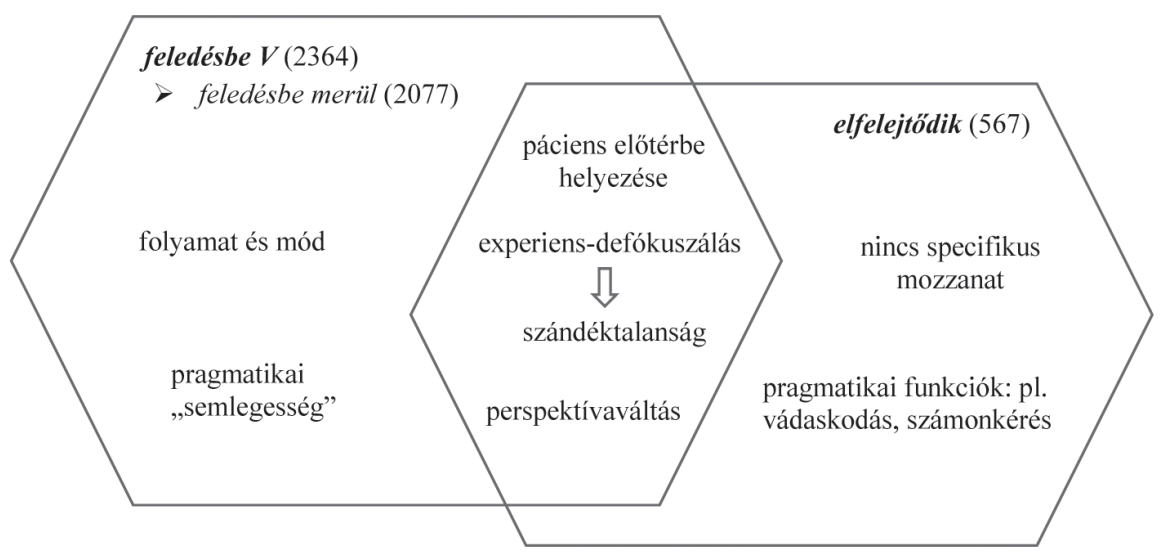

2. ábra. A feledésbe $V$ 'elfelejtődik' szerkezetek és az elfelejtödik ige viszonya

\subsection{Versengő szerkezetek}

A feledésbe $V$ 'elfelejtödik' kifejezések vizsgálata során egyértelmüvé vált, hogy - bár a feledésbe kerül jelentése a legáltalánosabb - a szinonimakörön belül a szinkróniában a feledésbe merül tekinthető a leggyakoribb és ezzel együtt a leginkább központi szerkezetnek, amely köré az adott funkcióigés szinonimakör szerveződik.

3. táblázat. A feledésbe merül, a feledésbe megy és a feledésbe kerül gyakorisága (MNSZ2)

\begin{tabular}{|c|c|}
\hline Feledésbe $\boldsymbol{V}$ & Gyakoriság \\
\hline merül & 2077 \\
\hline megy & 227 \\
\hline kerül & 16 \\
\hline
\end{tabular}

A 3. táblázatban szereplő gyakorisági adatok a feledésbe merül kiemelt, centrális helyzetét támasztják alá - rávilágítva egyúttal arra is, hogy bár a funkcióige jelentésének általánossága releváns szempont a funkcióigés szerkezetek egyes típusainak 
elkülönítése során, a konkrét szinonimakörök szerveződését nem ez a szempont határozza meg. A következőkben arra keresem a választ, hogy időben hogyan változhatott a feledésbe $V$ 'elfelejtödik' szinonimakörön belüli pozíciója a 3. táblázatban kiemelt három kifejezésnek.

A vizsgált szinonimakörön belül - ahogyan ez az 1. és a 3. táblázat adataiból is kitünik - a szinkróniában kimagasló a feledésbe merül gyakorisága, ami adott esetben egyúttal a szerkezet nagymértékü konvencionalizálódottságára is utal. ${ }^{37}$ A Magyar történeti szövegtár rendelkezésre álló adatai azonban arra engednek következtetni, hogy a 19. század második és a 20. század első felében a szinonimakört még nem ez a kifejezés szervezte, illetve határozta meg. A 4. táblázat az adott időszakokon belül a korpuszbeli első előfordulások időrendjében tekinti át, hogy az MTSZ-nek az elmúlt közel 180 évböl ${ }^{38}$ származó szövegeiben a szinonimakör mely igékre épülő szerkezetei és milyen gyakorisággal fordulnak elő:

4. táblázat. A feledésbe V'elfelejtődik' szerkezeteinek igei elemei az MTSZ-ben

\begin{tabular}{|c|c|}
\hline \multicolumn{2}{|c|}{ 19. század (1841-től) } \\
\hline tünik & 1 \\
\hline merül & 1 \\
\hline megy & 11 \\
\hline jut & 1 \\
\hline süllyed & 1 \\
\hline 20. század (1900-tól) \\
\hline merül & 74 \\
\hline megy & 29 \\
\hline vész & 2 \\
\hline borul & 2 \\
\hline kerül & 1 \\
\hline szóródik & 1 \\
\hline süllyed & 1 \\
\hline
\end{tabular}

A táblázat adatainak értelmezése során fontos szem előtt tartani, hogy az említett, megközelítőleg 180 éves időtávlatot átfogó szöveganyagban összesen mindössze

${ }^{37}$ A szóban forgó funkcióigés szinonimakör jellemzése során egyenes arányosságot feltételezek a szerkezetek konvencionalizáltságának mértéke és gyakorisága között - szem előtt tartva ugyanakkor azt is, hogy a gyakoriság csupán egy a konvencionalizáltság mértékének lehetséges mutatói közül, és a két fogalom semmi esetre sem azonosítható egymással (vö. pl. Dogruöz-Gries 2012). A konvencionalitás és a gyakoriság fogalma közötti (lehetséges) összefüggésekkel elméleti szempontból a jelen dolgozat keretében nem foglalkozom.

${ }^{38}$ A keresést a korpusz teljes anyagán végeztem, nem szükítettem idősávra. A feledésbe szóalakra keresve az első 'elfelejtődik' jelentésü szerkezet - a feledésbe tünik - 1841-böl származott. 
125-ször fordult elö feledésbe $V$ 'elfelejtődik' szerkezet - ez az arányaiban rendkívül kis minta tehát semmi esetre sem teszi lehetővé a változási folyamatok árnyalt és megbízható rekonstruálását, illetve nem ad módot annak feltárására sem, hogy mely időszakokban hogyan szervezödött az adott szinonimakör, mely szerkezetek alkothatták, és hogyan viszonyul(hat)tak egymáshoz az egyes kifejezések. Néhány lehetséges összefüggés azonban - természetesen csupán feltételezésként - mégis megfogalmazható a fenti adatok alapján.

A 4. táblázat adataiból látható, hogy az adott szinonimakörhöz korábban is tartozhattak olyan hapaxszerü, alkalmi, (feltehetően) nem konvencionális kifejezések, amelyeknek mindössze egy vagy néhány előfordulása adatolható. (Ilyen például a feledésbe jut ${ }^{39}$ vagy a feledésbe szóródik, amelyekre az MNSZ2 korpusza egyáltalán nem ad találatot. Az utóbbi kifejezés esetében ez azonban nem az időbeli távolsággal magyarázható, hanem abból adódik, hogy az MNSZ2 és az MTSZ más-más szövegeket tartalmaz. A feledésbe szóródik 1963-ból adatolható, szokatlan, nem konvencionális volta pedig azzal függ össze, hogy lírai szövegben - Illyés Gyula egy versében - fordul elő: ugyanazon a virradaton szóródik távoli feledésbe az én marburgi strófám.)

Megállapítható emellett az is, hogy - az MNSZ2 korábban ismertetett adataival összhangban - a történeti adatok között is túlnyomó többségükben mozgásigékkel, illetve tulajdonképpeni jelentésükben mozgást kifejező igékkel alkotott szerkezetek fordulnak elö. Ez alól csupán az MTSZ-ben elsöként adatolható tünik, valamint a vész látszik kivételnek - ha azonban figyelembe vesszük, hogy a tünik a TESz. felfogása szerint eredetileg gondolatokkal, mentális folyamatokkal összefüggésbe hozható metaforikusan értett mozgást jelölt (pl. vkinek az eszébe, gondolataiba tünik vmi), ez az ige is beilleszthetővé válik a tágan értelmezett, nem feltétlenül konkrét fizikai értelemben vett helyváltoztatásra utaló mozgásigék sorába. A vész pedig feltehetően a mindkét ige jelentésében hangsúlyos 'megszünik észlelhetővé válni' mozzanattal összefüggésben - elsősorban a tünik analógiájára léphetett be a szerkezetbe.

Emellett feltünő, hogy a szinonimakörön belül az MTSZ adatai szerint is a feledésbe megy, illetve a feledésbe merül tekinthető a leginkább gyakorinak, míg a rendkívül általános jelentésü (funkció)igét tartalmazó feledésbe kerül és feledésbe jut mindöszsze egy-egy példában adatolható. Érdemes ugyanakkor közelebbről, részletesebben, szükebb időintervallumokat tekintve is megvizsgálni a fenti gyakorisági adatokat különösen a megy-gyel és a merül-lel alkotott versengő szerkezetek gyakoriságának változására fókuszálva:

${ }^{39}$ A feledésbe jut azonban csupán az MTSZ. korpuszában tekinthető hapaxnak; a Google összesen 70 találatot adott rá egy 2021. február 19-én lefuttatott keresés során. (Ezek között természetesen vannak ismétlődő és hibás találatok is, de a találati lista ezzel együtt is jól mutatja, hogy nem egyedi használatról és nem egyértelmüen archaikus formáról van szó.) Köszönöm Imrényi Andrásnak, hogy felhívta a figyelmemet ezekre az elöfordulásokra. 
5. táblázat. A feledésbe megy merül kerül gyakoriságának változása (MTSZ)

\begin{tabular}{|l|c|c|c|c|}
\hline & $\mathbf{1 8 4 1 - 1 8 9 9}$ & $\mathbf{1 9 0 0 - 1 9 4 9}$ & $\mathbf{1 9 5 0}$ után & Összesen \\
\hline feledésbe megy & 11 & 17 & 12 & 40 \\
\hline feledésbe merül & 1 & 19 & 55 & 75 \\
\hline feledésbe kerül & - & - & 1 & 1 \\
\hline
\end{tabular}

Vagyis a korpusz 19. századból származó szövegeiben egyértelműen a feledésbe megy fordul elő nagyobb gyakorisággal (megközelítőleg egy nagyságrenddel gyakrabban, mint a feledésbe merül), a 20. század első felében közel azonos a két kifejezésmód gyakorisága (17, illetve 19 előfordulással), a 20. század második felében azonban a feledésbe merül válik elterjedtebbé. Az 5. táblázatnak a 20. század utolsó kb. kétharmadára vonatkozó adatai összhangban vannak az MNSZ2 gyakorisági adataival.

Ha számításba vesszük az egyes igéknek az előző, 5. alpontban említett szemantikai sajátosságait, valamint azt, hogy a feledésbe $V$ 'elfelejtődik' kifejezések a feledést olyan BENT helyként teszik hozzáférhetővé, ahová az emlékek a felejtési folyamat során/eredményeként kerülnek be, érthetővé válik, miért lehetett kitüntetett szerepe a szinonimakörön belül a prototipikus mozgásigének tekinthetö - viszonylag általános jelentésü, ugyanakkor az emlékeket antropomorfizáltan, önálló, szándékos mozgásra képes entitásokként megkonstruáló - megy-gyel alkotott szerkezetnek. Arra a kérdésre, hogy a feledésbe megy szerkezet helyett hogyan válhatott mégis a feledésbe merül központi, a szinonimakört szervező szerepü kifejezéssé, a következö, 6.3. alpontban térek vissza részletesebben.

\subsection{A feledésbe merül központivá válását motiváló tényezők}

Felmerül a kérdés, hogy - bár a szinonimakört összetartó elfelejtődik-hez szemantikai szempontból a feledésbe kerül van a legközelebb - miért a feledésbe merül áll a vizsgált szinonimakör középpontjában, ${ }^{40}$ illetve mi indokolhatja, hogy az adott konstrukcióban a merül használata néhány évtized alatt számottevően gyakoribbá vált, mint a 19. század során feltehetően még tipikusabbnak tekintett megy (vö. 4. táblázat).

A feledésbe $V$ 'elfelejtődik' konstrukcióban előforduló igék listáját (1. táblázat) áttekintve látható, hogy a merül szemantikai szempontból a nagyon specifikus jelentésü (pl. szitál) és a nagyon általános jelentésü (pl. kerül) igék között helyezkedik el: jelentése nem túl specifikus, de nem is túl általános. Az igének, illetve az ige jelentésének ez a sajátossága - mivel lehetővé teszi az adott kifejezés viszonylag

${ }^{40}$ A feledésbe merül centrális pozícióját a 3-5. táblázatban szereplő gyakorisági adatok támasztják alá. 
széles körü használatát ${ }^{41}$ - feltehetően nagymértékben hozzájárult a feledésbe merül szerkezet konvencionálissá válásához.

$\mathrm{Az}$ 5. pont elemzéseit figyelembe véve lényeges tényezőnek látszik emellett az is, hogy a merül-nek mozgásigeként tipikus és gyakori vonzatai a - $b A$ ragos névszói elemek. Ugyanakkor ez az ige nemcsak szerkezetileg, hanem szemantikailag is nagyon szorosan kapcsolódik a feledés(be) elemhez azáltal, hogy a felejtési folyamat inherensnek tételezhető és meghatározó mozzanataira - a tudat mélyére való alámerüléssel összefüggésben értelmezett hozzáférhetetlenné válásra - is utal, miközben a felejtést viszonylag lassú, fokozatosan végbemenő folyamatként konstruálja meg, amelynek eredményeként a feledésbe merülő emlékek nem bomlanak fel, nem szünnek meg létezni, csupán (átmenetileg vagy végérvényesen) elérhetetlenné, előhívhatatlanná és manipulálhatatlanná válnak. ${ }^{42} \mathrm{~A}$ feledésbe merül tehát a funkcióigés szerkezetek azon típusához - a szövetséget köt típushoz - tartozik, amelyek esetében az igei elem a névszó jelentésének valamely sajátos, központi mozzanatát vagy mozzanatait teszi hangsúlyossá (vö. 1. alpont).

Mindezek alapján - bár egyetlen szinonimakör vizsgálata természetesen nem teszi lehetővé az általános érvényü következtetések megfogalmazását - feltételezhető, hogy a funkcióigés szerkezetek esetében a szinonimakörök szerveződésének alakulásában, illetve abban, hogy mely kifejezés válik centrálissá az adott szinonimakörön belül, nem a szinonim igéhez való szemantikai közelség mértéke játszik meghatározó szerepet. Ennél jelentősebb szempontnak látszik az, hogy a szerkezet igei elemének jelentése - sem általánosságából, sem specifikusságából adódóan - ne korlátozza jelentős mértékben a szerkezet használati körét (és ezzel együtt a konvencionalizálódást), valamint hogy az ige az ábrázolt folyamat lényegi(ként felfogott) mozzanatait ragadja meg.

${ }^{41}$ Érdemes itt utalni a grammatikalizációs kutatások azon megállapítására - bár ez esetben grammatikalizációról természetesen nem beszélhetünk-, amely szerint a grammatikalizációs folyamatok tipikusan alapszintü kategóriákat megnevező nyelvi egységekből indulnak ki (pl. Heine-Claudi-Hünnemeyer 1991: 32-6; Ladányi 1999: 126-7; Dér 2008). Alapvetően mind a tapasztalás, mind pedig a tapasztalatok nyelvi megkonstruálása az alapszintủ kategóriákhoz kötődik, és ezzel együtt jellemzően az alapszintủ kategóriákat megnevező nyelvi egységek használati köre a legkevésbé korlátozott - vagyis ezek a kifejezések tágabb körben, illetve számottevően több kontextusban alkalmazhatók, mint a specifikusabb vagy az általánosabb (alá- vagy fölérendelt kategóriákra vonatkozó) megnevezések. Mindez részben magyarázatot adhat arra, hogy a feledésbe merül miért konvencionálisabb a specifikusabb, illetve általánosabb jelentésủ igét tartalmazó variánsokhoz képest.

${ }^{42}$ Hasonló mozzanatokat állít előtérbe a süllyed is, ez az ige azonban - a merül-lel szemben - értékelést, implicit értékítéletet is hordoz (vö. 5.2.), így használati köre korlátozottabb. A versengő szerkezetek között említett megy pedig elsősorban a feledésbe (mint BENT helyre) való bekerülésre vonatkozik, és a felejtést metaforikus értelemben vett mozgásként jeleníti meg, a folyamat sajátosságaira azonban nem utal, így kevésbé szorosan kapcsolódik mind a feledésbe vonzathoz, mind a feledésbe $V$ 'elfelejtődik' konstrukcióhoz, mint a merül. 


\section{7. Összegzés és kitekintés}

Jelen kutatásomban egyetlen funkcióigés szinonimakört, a feledésbe $V$ 'elfelejtödik' típusú szerkezeteket vizsgáltam alapvetően szemantikai szempontból. Az elsődlegesen problémafelvető jellegủ dolgozatban nem volt célom a vizsgált jelenségekkel - így például a jelentésváltozással, a funkcióigés szerkezetek értelmezésével vagy a szinonímiával - összefüggésben felmerülő elméleti kérdések tárgyalása; csupán a korpuszadatok kvalitatív elemzése nyomán körvonalazódó és a 2. alpontban megfogalmazott kutatási kérdések szempontjából releváns főbb feltételezések, illetve következtetések megfogalmazására tettem kísérletet.

A kutatás alapfogalmainak, célkitüzéseinek és módszertani alapvetéseinek rövid felvázolása után, a 4. alpontban - a vizsgált szinonimakört tágabb nyelvi öszszefüggésrendszerbe helyezve - a feledésbe $V$ 'elfelejtödik' típusú szerkezeteket az emlékekre, az emlékezésre és a felejtésre vonatkozó (adott esetben szükségszerüen metaforikus jelentésü) kifejezések rendszerén belül értelmeztem.

Ezt követően, az 5. alpontban azt vizsgáltam meg, hogy a) szerkezeti szempontból mennyire illeszkednek az egyes igék a feledésbe $V$ szerkezetbe, valamint hogy b) a szinonim funkcióigés szerkezetek igei elemei milyen sajátos mozzanatokkal járulnak hozzá a szerkezet jelentéséhez, illetve a felejtési folyamat mely sajátosságaira irányítják a figyelmet.

A 6. alpont az adott szinonimakör szerveződésével foglalkozott. Ebben a szerkezeti egységben elsősorban arra kerestem a választ, hogy mely szerkezet és miért kerülhetett centrális pozícióba az adott szinonimakörön belül, valamint hogy milyen tényezők járulhattak hozzá ahhoz, hogy éppen az adott szerkezet vált (a leginkább) konvencionálissá. A feledésbe merül esetében ilyen tényezö lehet az, hogy a merül jelentése nem túl általános, ám nem is túl specifikus jelentés, valamint hogy az adott ige szerkezeti és szemantikai szempontból egyaránt jól illeszkedik és szorosan kapcsolódik a feledésbe névszói elemhez, specifikus jelentésmozzanatai pedig a felejtés folyamatának - illetőleg a feledésbe vonzat jelentésének - lényegi, döntő mozzanatait emelik ki.

A felhasznált példaanyag vizsgálata ugyanakkor számos további, a dolgozat kérdésfelvetéséhez és célkitüzéseihez kapcsolódó, de azokon részben túlmutató kérdést és problémát is felvetett, amelyekre a kutatás keretein belül nem volt lehetöség kitérni. Ezek közül a következőkben csupán néhány fontosabbnak látszó lehetséges kutatási irányt említek.

Jelen kutatásom a funkcióigés szinonimakörök sajátosságait, illetve a szinonimakörök szervezödését befolyásoló tényezőket csupán egyetlen szinonimakörrel összefüggésben vizsgálta. Az elemzéseket érdemes volna a jelenleginél nagyobb anyagon, lényegesen több szerkezet bevonásával is elvégezni - ennek eredményeként feltehetően nagymértékben árnyalódna az itt kirajzolódott kép.

További fontos kérdés lehet annak feltárása, hogy a gyakoriság és a konvencionalitás hogyan, milyen mértékben és milyen esetekben befolyásolhatja a különböző funkcióigés szinonimakörök szerveződését, valamint hogy milyen más tényezők határozzák meg, hogy mely kifejezés(ek) válnak centrális pozíciójúvá egy adott szinonimakörön belül. 
A feledésbe $V$ 'elfelejtődik' szinonimakör esetében viszonylag nagymértékü variálódás mutatható ki. A fentebb felvetettek mellett kérdésként merülhet fel, hogy más funkcióigés szerkezetek körében is megfigyelhetö-e a variabilitás, és ha igen, milyen mértékben. A korpuszadatok arra utalnak, hogy a variálódás nem minden esetben jellemző (pl. esküt tesz), és a variabilitás mértéke is nagy eltéréseket mutat a különböző szinonimakörökön belül (pl. a barátságot $V$ '(össze)barátkozik' vagy a szövetséget $V$ 'szövetkezik' az MNSZ2 adatai szerint lényegesen kisebb mértékben variálódik, mint a sötétségbe $V$ 'elsötétedik' vagy a pillantást $V$ [vmire] 'rápillant'). Ezzel összefüggésben érdemes lenne megvizsgálni azt is, hogy milyen tényezők befolyásolhatják a változatosság mértékét, illetve az egyes szinonimakörök kiterjedését.

Bár a jelen dolgozat ezt a kérdéskört nem érintette, a feledésbe $V$ 'elfelejtődik' szerkezetek gyüjtése során nyilvánvalóvá vált, hogy ez a szinonimakör átfedésben van, illetve szorosan összekapcsolódik más szinonimakörökkel (homályba V'elhomályosul/elhomályosodik', sötét(ség)be $V$ 'elsötétül/elsötétedik') is. A jövőben tehát érdemes lenne a különbözö, egymással több ponton érintkező szinonimakörök közötti lehetséges viszonyokat, kölcsönhatásokat is megvizsgálni - mintegy tágabb szinonimakörben helyezve el és tágabb összefüggésrendszerben szemlélve ezáltal a feledésbe $V$ 'elfelejtődik' szerkezeteket.

\section{SZAKIRODALOM}

Bowern, Claire 2008. The diachrony of complex predicates. Diachronia 25: 161-85. https://doi. org/10.1075/dia.25.2.03bow

Butt, Miriam - Lahiri, Aditi 2013. Diachronic pertinacity of light verbs. Lingua 135: 7-29. https:// doi.org/10.1016/j.lingua.2012.11.006

Caygill, Howard 2010. Physiological Memory Systems. In: Radstone, Susannah - Schwarz, Bill (eds.): Memory. Histories, Theories, Debates. Fordham University Press, New York, 227-32.

Cetnarowska, Bożena 2014. How light are „light” verbs in composite predicates? In: Łyda, Andrzej-Drożdż, Grzegorz (eds.): Dimensions of the Word. Cambridge Scholars Publishing, Newcastle upon Tyne, 28-46.

Csépe Valéria - Győri Miklós - Ragó Anett (szerk.) 2007. Általános pszichológia 2. Tanulás - emlékezés - tudás. Osiris Kiadó, Budapest, 159-271.

Dér Csilla Ilona 2008. Grammatikalizáció. Nyelvtudományi Értekezések 158. Akadémiai Kiadó, Budapest.

Divjak, Dagmar 2006. Ways of intending. Delineating and structuring near-synonyms. In: Gries, Stefan Th. - Stefanowitsch, Anatol (eds.): Corpora in cognitive linguistics. Corpusbased approaches to syntax and lexis. Mouton de Gruyter, Berlin / New York, 19-56.

Dobos 2005. A funkcióigés szerkezetek belső valenciastruktúrája. In: Simigné Fenyő Sarolta - Bodnár Ildikó (szerk.): Sokszínü nyelvészet. Miskolci Egyetem, Miskolc, 17-26.

Dobos Csilla 2009. Funkcióigés szerkezetek. Miskolc.

Dogruöz, A. Seza - Gries, Stefan Th. 2012. Spread of on-going changes in an immigrant language. Turkish in the Netherlands. Review of Cognitive Linguistics 10/2: 401-26. https:// doi.org/10.1075/rcl.10.2.07sez

Domonkosi Ágnes 2006. Az emlékezet metaforái a magyar nyelvben. Publicationes Universitatis Miskolcinensis Section Philosophica XI: 19-28. 
Forgács Tamás 1998. Néhány megjegyzés a magyar igenemek kérdéséhez. Magyar Nyelv 84: 301-12.

Forgács Tamás 2007. Bevezetés a frazeológiába. A szólás- és közmondáskutatás alapjai. Tinta Könyvkiadó, Budapest.

Forgács Tamás 2015. Frazeológiai egységek „könnyü igékkel”. In: Bárth M. János - Bodó Csanád - Kocsis Zsuzsanna (szerk.): A nyelv dimenziói. Tanulmányok Juhász Dezső tiszteletére. ELTE BTK, Budapest, 462-72.

Glynn, Dylan 2014. The many uses of run. Corpus methods and Socio-Cognitive Semantics. In: Glynn, Dylan - Robinson, Justyna A. (eds.): Corpus methods for semantics. Quantitative studies in polysemy and synonymy. John Benjamins, Amsterdam/Philadelphia, 117-44. https://doi.org/10.1075/hcp.43.05gly

Glynn, Dylan 2016. Quantifying polysemy: Corpus methodology for prototype theory. Folia Linguistica 50/2: 413-47. https://doi.org/10.1515/flin-2016-0016

Glynn, Dylan - Robinson, Justyna A. (eds.) 2014. Corpus Methods for Semantics. Quantitative studies in polysemy and synonymy. John Benjamins, Amsterdam/Philadelphia. https://doi. org/10.1075/hcp.43

Hegedűs Rita 2004. Magyar nyelvtan. Formák, funkciók, összefüggések. Tinta Könyvkiadó, Budapest.

Heine, Bernd - Claudi, Ulrike - Hünnemeyer, Friederike 1991. Grammaticalization. A conceptual framework. The University of Chicago Press, Chicago/London.

Horváth Katalin 1996. Hogyan bővülnek a szinonimasorok? A poliszémia és a szinonímia összefüggéséröl. Magyar Nyelv 82: 325-31.

Hrenek Éva 2016. A funkcióigés szerkezetek a metaforikus jelentésü igei szerkezetek rendszerében. Diplomamunka. Kézirat. ELTE BTK Alkalmazott Nyelvészeti Tanszék, Budapest.

Hrenek, Éva 2019a. On the meaning of light verbs: Hungarian light verb constructions within the system of verbal constructions with metaphorical meanings. Jezyk, Komunikacja, Informacja / Language, Communication, Information 14: 14-32.

Hrenek Éva 2019b. Az igei jelentések elhatárolásának lehetséges szempontjai. Kézirat.

Imrényi András 2013. A magyar mondat viszonyhálózati modellje. Nyelvtudományi Értekezések 164. Akadémiai Kiadó, Budapest.

Imrényi András - Kugler Nóra - Ladányi Mária - Markó Alexandra - Tátrai Szilárd - Tolcsvai Nagy Gábor 2017. Nyelvtan. Osiris Kiadó, Budapest.

Ittzés, Máté 2015. Light verb constructions in Vedic. Manas. Studies into Asia and Africa 2/1. http://manas.bg/en/tradition-and-modernity-indian-culture/light-verb-constructionsvedic\#nav2

Ittzés Máté 2016. Funkcióigés szerkezetek a védikus óind nyelvben. Habilitációs dolgozat. Kézirat. ELTE BTK, Budapest.

Janda, Laura A. - Solovyev, Valery D. 2009. What constructional profiles reveal about synonymy. A case study of Russian words for sadness and happiness. Cognitive Linguistics 20/2: 367-93. https://doi.org/10.1515/COGL.2009.018

Kelemen Sándor - Ladányi Mária - Spannraft Marcellin 1985. Igei jelentéselemzések. Magyar Nyelvör 109: 218-34.

Keszler Borbála 2000. A szófaji felosztás problémái. In: Keszler Borbála (szerk.): Magyar grammatika. Nemzeti Tankönyvkiadó, Budapest, 70-6.

Knowlton, Barbara J. - Squire, Larry R. 1995. Remembering and knowing: two different expressions of declarative memory. Journal of Experimental Psychology Learning, Memory and Cognition 21/3: 699-710. https://doi.org/10.1037/0278-7393.21.3.699

Kövecses Zoltán 2005. A metafora. Gyakorlati bevezetés a kognitiv metaforaelméletbe. Typotex Kiadó, Budapest. 
Kugler Nóra 2021. Factivusszal kidolgozott eredményállapotot tartalmazó rezultatív konstrukciók a magyarban. Kognitív grammatikai elemzés. Argumentum. Megjelenés alatt.

Ladányi Mária 1993. Az eszik ige és szinonimái. Általános mozzanatok szerepe a metaforizációban és a szinonimitásban. In: Hadas Emese (szerk.): A metaforikus és a hipotetikus jelentés további konkretizációja. A, Nyelvi mozgásformák dialektikája” kutatócsoport munkái 10. ELTE BTK Általános és Alkalmazott Nyelvészeti Tanszék, Budapest, 13-41.

Ladányi Mária 1999. Poliszémia és grammatikalizáció. In: Gecső Tamás (szerk.): Poliszémia, homonímia. Segédkönyvek a nyelvészet tanulmányához 2. Tinta Kiadó, Budapest. 124-34.

Ladányi Mária 2004. Rendszeres igei poliszémia. In: Kiefer Ferenc (szerk.): Strukturális magyar nyelvtan 4. A szótár szerkezete. Akadémiai Kiadó, Budapest, 269-320.

Langacker, Ronald W. 1987. Foundation of Cognitive Grammar. Vol. 1. Theoretical Prerequisites. Stanford University Press, Stanford.

Langacker, Ronald W. 2009. Cognitive (Construction) Grammar. Cognitive Linguistics 20/1: 167-76. https://doi.org/10.1515/COGL.2009.010

Langer, Stefan 2005. A Linguistic Test Battery for Support Verb Constructions. Lingvisticae Investigationes 27/2: 171-84. https://doi.org/10.1075/li.27.2.03lan

Lanstyák István 2019. A funkcióigés szerkezetek néhány általános kérdéséről. Fórum Társadalomtudományi Szemle 21/4: 61-91.

Modrián-Horváth Bernadett 2020. Megszidódik és meg van szidva. A passzív funkciók morfoszintaktikai kifejezőeszközeinek korpuszalapú vizsgálata. In: Simon Gábor Tolcsvai Nagy Gábor (szerk.): Nyelvtan, diskurzus, megismerés. ELTE Eötvös Kiadó, Budapest, 200-28.

Murphy, Lynne 2003. Synonymy and similarity. In: Murphy, Lynne: Semantic relations and the lexicon. Cambridge University Press, Cambridge, 133-69. https://doi.org/10.1017/ CBO9780511486494.005

NyMDK. 1-11. = A „,Nyelvi mozgásformák dialektikája” kutatócsoport munkái 1-11. ELTE BTK Általános és Alkalmazott Nyelvészeti Tanszék, Budapest, 1982-1994.

Simon Gábor 2016. A metaforikus jelentés nyelvtanvezérelt megközelítése. Magyar Nyelvör 140: $178-99$.

Simon Gábor 2018. Az igei jelentés metaforizációjának mintázatai. Nyelvtan- és korpuszvezérelt esettanulmányok. Jelentés és Nyelvhasználat 5: 1-36. https://doi.org/10.14232/ jeny.2018.1.1

J. Soltész Katalin 1959. Az ösi magyar igekötők (meg, el, ki, be, fel, le). Akadémiai Kiadó, Budapest.

Squire, Larry R. 2004. Memory systems of the brain: a brief history and current perspective. Neurobiology of Learning and Memory 82/3: 171-7. https://doi.org/10.1016/j. nlm.2004.06.005

Sutton, John - Harris, Celia B. - Barnier, Amanda J. 2010. Memory and Cognition. In: Radstone, Susannah - Schwarz, Bill (eds.): Memory. Histories, Theories, Debates. Fordham University Press, New York, 209-26.

Zsilka János 1975. A jelentés szerkezete. (A jelentés-mozgás egysége). Akadémiai Kiadó, Budapest.

Zsilka János 1978. Jelentés-integráció. Akadémiai Kiadó, Budapest.

Zsilka János 1982. De constructione. Történet és állapot egysége a nyelvben. Akadémiai Kiadó, Budapest.

\section{FORRÁSOK}

ÉKsz. ${ }^{1}$ = Juhász József - Szőke István - O. Nagy Gábor - Kovalovszky Miklós (szerk.) 1972. Magyar értelmezö kéziszótár. Akadémiai Kiadó, Budapest. 
ÉKsz. ${ }^{2}=$ Pusztai Ferenc (föszerk.) 2003. Magyar értelmező kéziszótár. Akadémiai Kiadó, Budapest.

ÉrtSz. = Bárczi Géza - Országh László (főszerk.) 1959-1962. A magyar nyelv értelmezö szótára. I-VII. Akadémiai Kiadó, Budapest.

Mazsola = Mazsola - a magyar igei bövítményszerkezet vizsgálata . http://corpus.nytud.hu/ mazsola

MNSZ2 = Magyar Nemzeti Szövegtár 2. http://clara.nytud.hu/mnsz2-dev

MTSZ = Magyar Történeti Szövegtár. http://clara.nytud.hu/mtsz

Nsz. = Ittzés Nóra (föszerk.) A magyar nyelv nagyszótára. I-VI. 2006-2017. Akadémiai Kiadó, Budapest.

TESz. = Benkő Loránd (föszerk.) 1967-1976. A magyar nyelv történeti-etimológiai szótára. I-III. Akadémiai Kiadó, Budapest.

\author{
Hrenek Éva \\ ELTE Nyelvtudományi Doktori Iskola \\ Magyar nyelvészet doktori program \\ https://orcid.org/0000-0002-4232-8528
}

\title{
SUMMARY
}

Hrenek, Éva

\section{Synonymy in light verb constructions of the type feledésbe + verb}

This paper discusses the phenomenon of synonymy in light verb constructions, primarily with a problem raising character, and analysing a single set of synonyms: the range of variants of the construction feledésbe + verb 'be forgotten' (e.g., feledésbe merül $\sim$ kerül $\sim$ megy enyészik 'fall/pass/sink/slip/slide/fade into oblivion'). After sketching the notion and types of light verb constructions, the paper gives an overview of what kinds of metaphorical expressions typically make it possible to grasp the two inseparable concepts of memory and oblivion, and how the constructions under study here fit into the range of those possible ways of expression. Next, we try to find out what specific particulars the verbs occurring in the diverse variants of the given construction contribute to the meaning of the construction, and in what respects they make the process of forgetting linguistically accessible. The second main part of the paper offers a more detailed exploration of which construction(s) within the synonym set delineated by the variants of the construction type feledésbe $V$ 'be forgotten' can be taken to be the central one(s) and why - primarily in a synchronic perspective but, as far as the available linguistic data make this possible, also taking the assumable diachronic changes into consideration.

Keywords: synonymy, light verb constructions, variability, polysemy, verb semantics 